\title{
Water as a reactant in the differential expression of proteins in cancer
}

\author{
Jeffrey M. Dick ${ }^{1, *(\mathbb{D})}$ \\ 1 Key Laboratory of Metallogenic Prediction of Nonferrous Metals and Geological Environment Monitoring, \\ Ministry of Education, School of Geosciences and Info-Physics, Central South University, Changsha, China \\ * Correspondence: jeff@chnosz.net
}

Preprint compiled on June 3, 2020

1 Abstract: How the abundances of proteins are shaped by tumor microenvironments, such as hypoxic 2 conditions and higher water content compared to normal tissues, is an important question for cancer 3 biochemistry. Compositional analysis of more than 250 datasets for differentially expressed proteins 4 compiled from the literature reveals a higher stoichiometric hydration state in multiple cancer types 5 compared to normal tissue; this trend is also evident in pan-cancer transcriptomic and proteomic 6 datasets from The Cancer Genome Atlas and Human Protein Atlas. These findings support the notion 7 of a basic physicochemical link between increased water content in tumors and the patterns of gene 8 and protein expression in cancer. The generally increased hydration state is juxtaposed with a wide - spectrum of carbon oxidation states of differentially expressed proteins, which may be associated 10 with different gene ages, host tissue properties and metabolic features of specific cancer types.

Keywords: proteomes; chemical composition; water content; hypoxia; 3D cell culture; proliferation

\section{Introduction}

Although cancer is usually regarded as being driven primarily by genetic mutations [1], alterations in cancer cell metabolism and tumor microenvironment are also crucial for the growth of cancer cells. Together with extracellular acidosis due to increased glycolysis [2], changes in water and oxygen content are major chemical characteristics of cancer. Hypoxia, or less than normal physiological concentration of oxygen, in tumor microenvironments plays a major role in the biochemistry, physiology and progression of cancer [3]. Cancer tissue also has a relatively high water content [4], as consistently demonstrated by early desiccation experiments [5]. More recent developments of spectroscopic methods further substantiate the generally higher water content of cancer tissue [6,7]. These observations are consistent with the hypothesis that higher cellular hydration in carcinogenesis is a major factor that is shared with embryonic conditions [8]. Moreover, water content is a key player in other aspects of cell biology such as entry into dormancy [9]. Nonetheless, the connections between cellular water content and biomolecular abundances are not well understood.

Differences in the abundances of many proteins are a major outcome of the combination of genetic, microenvironmental and metabolic alterations in cancer. In a genocentric view of metabolism, the myriad reactions underlying changes to the proteome are catalyzed and regulated by the enzymatic products of the genome, but an adequate biochemical description should also account for the chemical compositions of the proteins themselves. From a geochemical perspective, a natural question to ask is whether the chemical compositions of differentially expressed proteins are shaped by the physicochemical conditions of tumor microenvironments.

In addition to the altered oxygenation and hydration status of tumors, the observation that most biochemical transformations involve some combination of oxidation-reduction and hydration-dehydration reactions $[10,11]$ leads to the hypothesis that changes of oxidation and hydration state of biomolecules constitute primary biochemical variables. The sensitivity of metabolic reactions to hypoxia is well documented; for example, the reduction of metabolites under hypoxic conditions is possible by running the TCA cycle in reverse [12], and hypoxic regions in tumors accelerate the reduction of nitroxide, a redox-sensitive contrast agent used in magnetic resonance 


\section{imaging $[13,14]$. However, hypoxia also induces the mitochondrial production of reactive oxygen species [15], so it would be an oversimplification to state that hypoxia leads to uniformly more reducing intracellular conditions. Cellular hydration state also has wide-ranging effects on cell metabolism [16], but no previous studies have systematically characterized chemical metrics of oxidation and hydration state at the proteome level in cancer.}

In a short section on "Water as a Reactant", a popular biochemistry textbook [17] describes a few types of reactions involving the release of $\mathrm{H}_{2} \mathrm{O}$ as a product (oxidation of glucose, condensation reactions) or its consumption as a reactant (water splitting in photosynthesis, and hydrolysis, the reverse of condensation). The polymerization of amino acids is a type of condensation reaction that is fundamental to protein synthesis, but the stoichiometry of the reactions depends only on protein length; one water is lost for each peptide bond formed between any two amino acids. A more specific metric is needed to quantify the amount of $\mathrm{H}_{2} \mathrm{O}$ gained or lost in the differential expression of proteins with different amino acid compositions.

Without considering detailed biosynthetic mechanisms, it is possible to use compositional metrics, which are derived from the elemental composition of proteins, to quantify the net differences in the degree of oxidation (oxidation state) and hydration (hydration state) between distinct proteins. An important theoretical consideration in deriving these metrics is that, unlike oxidation-reduction reactions, hydration-dehydration reactions do not involve the transfer of electrons, that is, they are redox-neutral. This reasoning underlies the development of a compositional metric called the stoichiometric hydration state [18]. Combined with calculations of carbon oxidation state, this makes it possible to quantify compositional differences of proteins in two dimensions that are predicted to be independent indicators of environmental oxygen and water content.

My previous analysis of proteomic data provided preliminary evidence for a higher hydration state of proteomes in colorectal and pancreatic cancer [19]. That compilation of differential expression data is expanded here to include breast, liver, lung and prostate cancer. Proteomic data are also considered for laboratory experiments of hypoxia, because of its relevance to cancer [3], and hyperosmotic stress, which has not been reported for cancer cell lines, but permits testing the sensitivity of the compositional analysis to changes in hydration state. Furthermore, I separately analyze proteomic data for both cellular and secreted proteins in hypoxia compared to normoxic controls. I also consider differential expression data for 3D culture conditions; compared to 2D or monolayer growth, the formation of cell aggregates, spheroids, or organoids in 3D culture more closely represents the tissue environment [20,21]. Finally, I combine the differential expression data with gene ages to get a picture of the evolutionary trajectories of chemical composition.

By analyzing the chemical compositions derived from proteomic datasets for particular cancer types and cell culture conditions, as well as pan-cancer transcriptomic and proteomic data, I show that hyperosmotic and 3D culture conditions in laboratory experiments induce the expression of proteins with an overall lower hydration state, whereas a higher hydration state characterizes the populations of proteins that are up-regulated in most cancer types. Therefore, the differential expression of proteins in most cancer types can be characterized theoretically as an overall biochemical reaction that consumes water as a reactant; this may be a novel biochemical manifestation of the generally elevated water content in tumors. In contrast, different cancer types show a wide range of carbon oxidation states of differentially expressed proteins, which therefore do not appear to be driven by the general condition of tumor hypoxia. Instead, the changes in oxidation state can be correlated with gene ages and might be associated with specific tissue and metabolic characteristics of different cancer types.

\section{Results}

Extensive literature searches were performed to build a database of differentially expressed proteins in five cell culture conditions versus controls and primary cancers of six organs compared to normal tissue (Fig. 1). Multiple datasets for each condition and cancer type were considered in order to compensate for inevitable technical and biological variability. In total, 301 datasets were obtained 


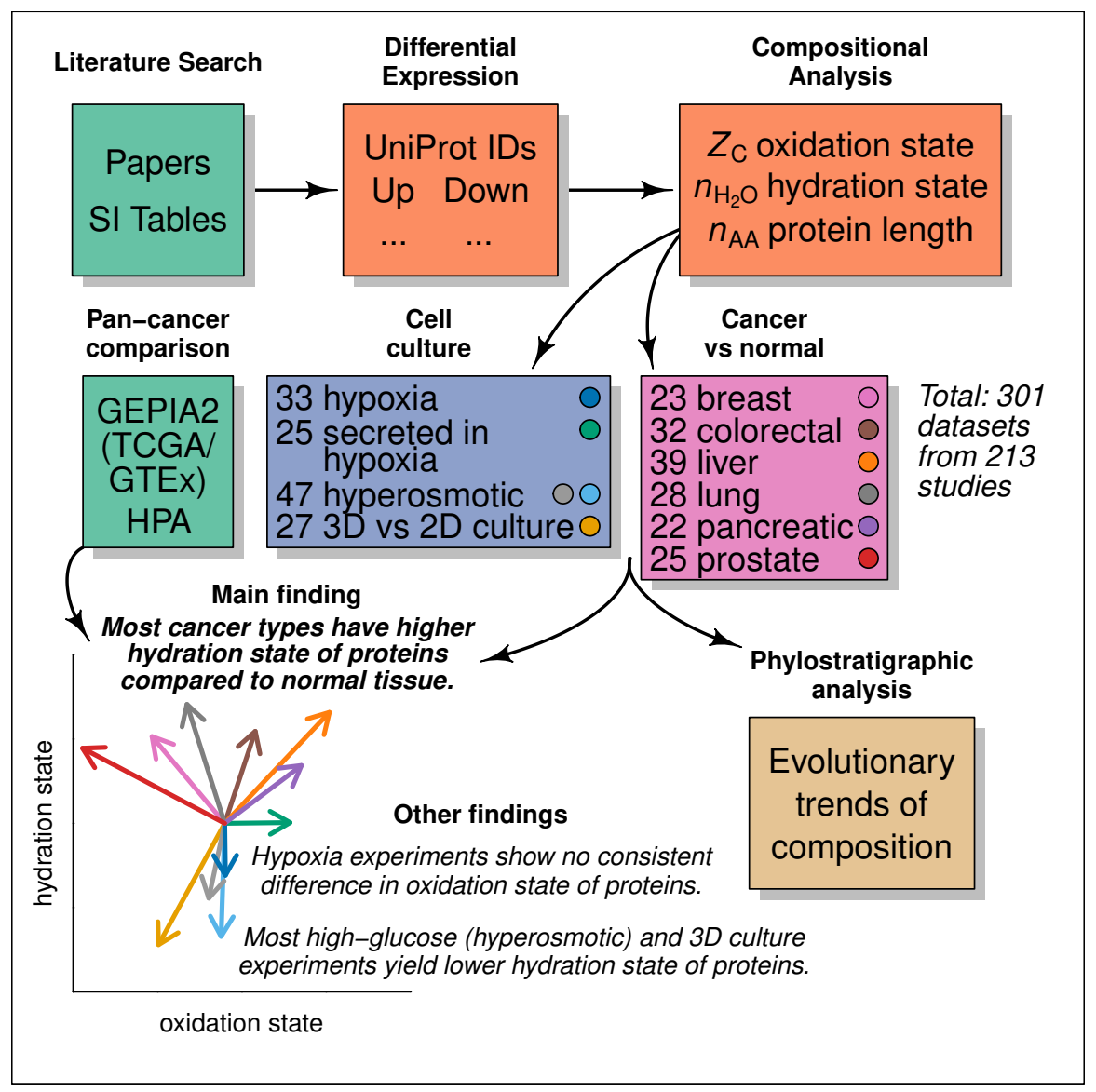

Figure 1. Study overview. Abbreviations: SI - Supplementary Information; GEPIA2 - Gene Expression Profiling Interactive Analysis web server; TCGA - The Cancer Genome Atlas; GTEx - Genotype-Tissue Expression project; HPA - Human Protein Atlas. The number of datasets listed for hyperosmotic conditions includes both high-salt (22) and high-glucose (25) experiments. The arrow diagram represents the mean values of differences of hydration state $\left(\Delta n_{\mathrm{H}_{2} \mathrm{O}}\right)$ and oxidation state $\left(\Delta \mathrm{Z}_{\mathrm{C}}\right)$ for all datasets in each condition (see Table 2).

from 213 studies for cell extracts in hypoxia [22-43], secreted proteins in hypoxia [31,33,39,44-59], hyperosmotic stress represented by high salt [60-70] or high glucose [71-85], 3D vs 2D cell culture [86104], and breast [105-121], colorectal [122-147], liver [148-176], lung [177-196], pancreatic [197-217], and prostate [218-234] cancer.

The carbon oxidation state $\left(Z_{C}\right)$ and stoichiometric hydration state $\left(n_{\mathrm{H}_{2} \mathrm{O}}\right)$ (Table 1$)$ are compositional metrics derived from the chemical formulas of amino acids; therefore, they do not denote any particular biological mechanisms for amino acid synthesis. All of the calculations in this study are based on differences in the chemical composition of proteins as determined by their primary sequences, and do not take account of post-transcriptional modifications, like the oxidation of cysteine to make disulfide bonds, or the presence of water molecules in the hydration shell of folded proteins.

Carbon oxidation state for biomolecules lies between the extremes of -4 for $\mathrm{CH}_{4}$ and +4 for $\mathrm{CO}_{2}$ (see Figure 1 of ref. [235]). Because it is based on the relative electronegativities of elements, it can be calculated directly from the elemental composition of proteins $[236,237]$. On the other hand, a metric for hydration state depends on the stoichiometry of water in balanced chemical reactions. Since reactions that consume or release only water do not involve the transfer of electrons, a useful metric for hydration state should not be correlated with oxidation state for a collection of proteins (i.e. all those coded by the genome). Following this reasoning, the basis species glutamine-glutamic acid-cysteine- $\mathrm{H}_{2} \mathrm{O}-\mathrm{O}_{2}$ were selected to write theoretical formation reactions of amino acids; the 
Table 1. Average oxidation state of carbon $\left(Z_{C}\right)$, number of carbon atoms $\left(n_{C}\right)$, and stoichiometric hydration state $\left(n_{\mathrm{H}_{2} \mathrm{O}}\right)$ of amino acid residues computed using the rQEC derivation (see Materials and Methods and ref. [18]).

\begin{tabular}{lrrrlrrr}
\hline $\mathbf{A A}$ & $\boldsymbol{Z}_{\mathbf{C}}$ & $n_{\mathbf{C}}$ & $n_{\mathbf{H}_{2} \mathbf{O}}$ & $\mathbf{A A}$ & $Z_{\mathbf{C}}$ & $n_{\mathbf{C}}$ & $n_{\mathbf{H}_{2} \mathbf{O}}$ \\
\hline $\mathrm{A}$ & 0 & 3 & 0.369 & $\mathrm{M}$ & $-2 / 5$ & 5 & 0.046 \\
$\mathrm{C}$ & $2 / 3$ & 3 & -0.025 & $\mathrm{~N}$ & 1 & 4 & -0.122 \\
$\mathrm{D}$ & 1 & 4 & -0.122 & $\mathrm{P}$ & $-2 / 5$ & 5 & -0.354 \\
$\mathrm{E}$ & $2 / 5$ & 5 & -0.107 & $\mathrm{Q}$ & $2 / 5$ & 5 & -0.107 \\
$\mathrm{~F}$ & $-4 / 9$ & 9 & -2.568 & $\mathrm{R}$ & $1 / 3$ & 6 & 0.072 \\
$\mathrm{G}$ & 1 & 2 & 0.478 & $\mathrm{~S}$ & $2 / 3$ & 3 & 0.575 \\
$\mathrm{H}$ & $2 / 3$ & 6 & -1.825 & $\mathrm{~T}$ & 0 & 4 & 0.569 \\
$\mathrm{I}$ & -1 & 6 & 0.660 & $\mathrm{~V}$ & $-4 / 5$ & 5 & 0.522 \\
$\mathrm{~K}$ & $-2 / 3$ & 6 & 0.763 & $\mathrm{~W}$ & $-2 / 11$ & 11 & -4.087 \\
$\mathrm{~L}$ & -1 & 6 & 0.660 & $\mathrm{Y}$ & $-2 / 9$ & 9 & -2.499 \\
\hline
\end{tabular}

number of water molecules in these reactions (Table S1) was used as input to a residual analysis to further reduce the covariation with $Z_{C}$ (Fig. S1), giving the residual-corrected stoichiometric hydration state listed in Table 1. This derivation, denoted "rQEC", is briefly described in the Materials and Methods; see ref. [18] for more details and conceptual background.

\subsection{Compositional Differences in Cell Culture Conditions and Cancer Compared to Normal Tissue}

The compositional analysis of differentially expressed proteins is presented in scatterplots of median $\Delta n_{\mathrm{H}_{2} \mathrm{O}}$ and $\Delta \mathrm{Z}_{\mathrm{C}}$, that is, the median value for all up-regulated proteins minus the median value for all down-regulated proteins in each dataset (Fig. $2 A$ and $B$ ). The median differences for all datasets in each condition were used to compute the $50 \%$ credible regions for highest probability density using code adapted from the "HPDregionplot" function in the R package emdbook [238], which in turn uses two-dimensional kernel density estimates calculated with "kde2d" in the R package MASS [239]. Plots with references and descriptions for all datasets are provided in Figs. S6-S16.

Several broad trends emerge from the compositional analysis of differentially expressed proteins in cell culture conditions. Differentially expressed proteins reported for cell extracts under hypoxia do not show consistent differences in oxidation state (Fig. 2A). However, differentially expressed proteins in many datasets for secreted proteins in hypoxia are somewhat oxidized $\left(\Delta Z_{C}>0\right)$. Although the wider credible region for secreted proteins indicates a larger variability (Fig. $2 C$ ), the shift toward higher $Z_{C}$ is statistically significant for these datasets (Table 2). Hyperosmotic stress results in the formation of proteins with predominantly lower hydration state $\left(\Delta n_{\mathrm{H}_{2} \mathrm{O}}<0\right)$; the effect is stronger for high-glucose experiments than for high-salt experiments. Lower hydration state also characterizes the majority of 3D cell culture experiments, which in addition tend to have more reduced proteins $\left(\Delta Z_{C}<\right.$ 0 ). All of the 3D cell culture experiments analyzed here are for human or mouse cells, including some cancer cell lines, which are represented by filled circles in Fig. 2A. The experiments for cellular and secreted proteins in hypoxia include human and other mammalian cells. In contrast, the hyperosmotic stress experiments include mammalian as well as yeast cells; the latter are indicated by the squares in Fig. 2A. See the legends of Figs. S6-S10 for details about cell types and culture conditions.

There is a clear trend of increased hydration state of proteins $\left(\Delta n_{\mathrm{H}_{2} \mathrm{O}}>0\right)$ for five of the six cancer types for which multiple proteomic datasets were compiled (Fig. $2 B$ and $C$ ). The exception is pancreatic cancer, where the datasets are distributed more evenly among positive and negative $\Delta n_{\mathrm{H}_{2} \mathrm{O}}$. There are distinct trends in oxidation state of proteins for different cancer types: relatively oxidized proteins are up-regulated in colorectal, liver, and pancreatic cancer, whereas more reduced proteins are up-regulated in breast, lung, and prostate cancer.

The trends described above are also visible in the arrow diagram in Fig. 1. In this diagram, the lines are drawn from the origin to the mean difference of $Z_{\mathrm{C}}$ and $n_{\mathrm{H}_{2} \mathrm{O}}$ among all datasets for each cancer type and cell culture condition. The mean differences and $p$-values are listed in Table 2. 

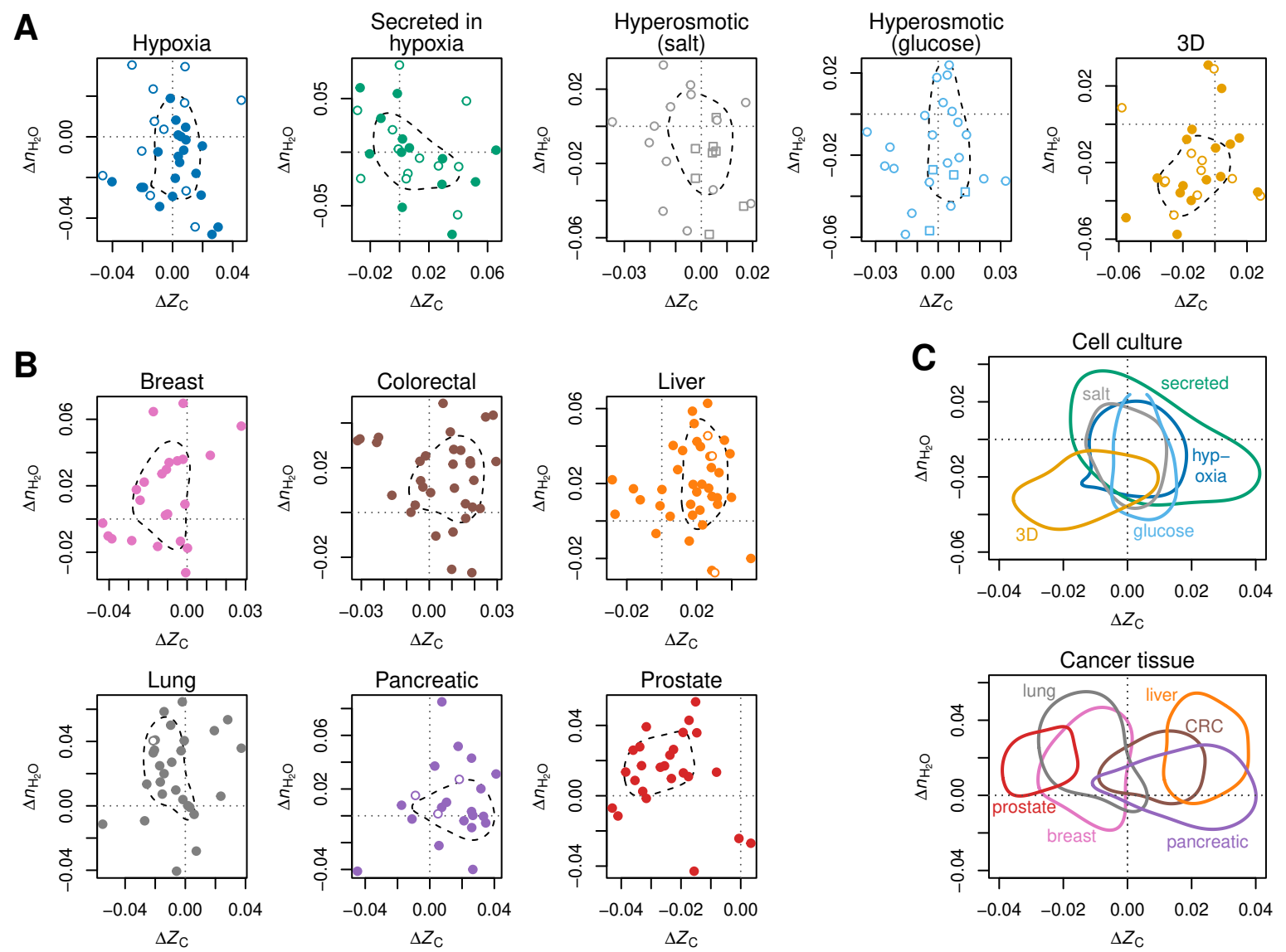

Figure 2. Compositional analysis of proteins identified in differential expression datasets. Median differences of stoichiometric hydration state $\left(\Delta n_{\mathrm{H}_{2} \mathrm{O}}\right)$ and average oxidation state of carbon $\left(\Delta \mathrm{Z}_{\mathrm{C}}\right)$ in (A) cell culture experiments and (B) cancer tissues. Each point represents an individual proteomics dataset; positive value of $\Delta$ indicate a higher median value for the up-regulated proteins. For cell culture experiments, open and filled symbols represent non-cancer and cancer cells, respectively, and squares represent yeast cells. Open symbols for cancer datasets represent mouse or rat models; all others are from human subjects. Dashed lines indicate the $50 \%$ credible region for highest probability density for all datasets for each condition. (C) Comparison of the 50\% credible regions for cell culture and cancer tissue. Abbreviation: CRC - colorectal cancer.

All cancer types have positive mean $\Delta n_{\mathrm{H}_{2} \mathrm{O}}$, indicating greater hydration state of the up-regulated proteins, but the difference for pancreatic cancer is less statistically significant ( $p$-value $>0.05$ ). In contrast, hyperosmotic stress and 3D cell culture conditions, and to a lesser degree, cell extracts in hypoxia, show the up-regulation of proteins with significantly lower hydration state.

\subsection{Elevated Hydration State and Variable Oxidation State in Pan-Cancer Datasets}

Compositional analysis of large-scale pan-cancer datasets is important for assessing the differences between cancer types, and for inquiring if changes in compositional metrics for proteins are reflected in the differential expression of the genes that code for the proteins. To characterize pan-cancer transcriptomes and proteomes in terms of chemical composition, I obtained data for differential gene expression between normal tissue and cancer from GEPIA2 [245], which uses pre-compiled data files from UCSC Xena [246] that are in turn derived from the Genotype-Tissue Expression project (GTEx) [247] and The Cancer Genome Atlas (TCGA) [248]. I used data from the Human Protein Atlas (HPA) $[244,249]$ to calculate differential protein expression as described in the Materials and Methods. 
Table 2. Mean differences for all differential expression datasets in each condition, followed by $\log _{10}$ of $p$-value in parentheses. $p$-values less than $0.05\left(\log _{10}<-1.3\right)$ are shown in bold.

\begin{tabular}{|c|c|c|c|c|c|}
\hline Condition & $\Delta Z_{C}$ & $\Delta n_{\mathrm{H}_{2} \mathrm{O}}$ & $\Delta \mathbf{P S}^{\mathbf{a}}$ & $\Delta \mathbf{P S}^{\mathbf{b}}$ & $\Delta n_{\mathrm{AA}}$ \\
\hline \multicolumn{6}{|l|}{ Cell culture ${ }^{\mathrm{c}}$} \\
\hline Hypoxia (cell extracts) & $0.000(-0.0)$ & $-0.009(-1.6)$ & $0.45(-2.5)$ & $0.18(-1.2)$ & $7.6(-0.1)$ \\
\hline Secreted in hypoxia & $0.011(-1.4)$ & $0.000(-0.0)$ & $0.26(-0.3)$ & $0.02(-0.0)$ & $-19.6(-0.3)$ \\
\hline Hyperosmotic (salt) & $-0.003(-0.5)$ & $-0.013(-1.5)$ & $-0.17(-0.7)$ & $-0.06(-0.1)$ & $16.4(-0.4)$ \\
\hline Hyperosmotic (glucose) & $-0.001(-0.1)$ & $-0.019(-3.6)$ & $-0.09(-0.2)$ & $-0.22(-0.4)$ & $11.3(-0.3)$ \\
\hline $3 \mathrm{D} / 2 \mathrm{D}$ & $-0.011(-2.0)$ & $-0.021(-4.2)$ & $0.14(-0.4)$ & $-0.08(-0.3)$ & $-12.6(-0.2)$ \\
\hline \multicolumn{6}{|l|}{ Cancer ${ }^{\mathbf{c}}$} \\
\hline Breast & $-0.012(-2.7)$ & $0.015(-\mathbf{- 1 . 7})$ & $-1.86(-6.4)$ & $-0.84(-5.9)$ & $-71.2(-1.8)$ \\
\hline Colorectal & $0.005(-1.1)$ & $0.016(-4.3)$ & $-0.50(-2.0)$ & $-0.31(-2.7)$ & $36.2(-1.0)$ \\
\hline Liver & $0.018(-6.7)$ & $0.019(-5.5)$ & $0.37(-1.4)$ & $0.54(-4.9)$ & $20.5(-0.9)$ \\
\hline Lung & $-0.006(-1.1)$ & $0.020(-3.4)$ & $-1.04(-2.8)$ & $-0.65(-2.7)$ & $-44.6(-0.9)$ \\
\hline Pancreatic & $0.013(-2.2)$ & $0.010(-0.9)$ & $1.07(-1.9)$ & $0.49(-\mathbf{1 . 5})$ & $29.5(-0.5)$ \\
\hline Prostate & $-0.024(-9.4)$ & $0.013(-2.0)$ & $-1.91(-8.9)$ & $-1.05(-9.5)$ & $-25.1(-0.4)$ \\
\hline \multicolumn{6}{|l|}{ Pan-cancer ${ }^{\mathbf{C}}$} \\
\hline TCGA / GTEx & $-0.009(-4.0)$ & $0.006(-2.8)$ & $-0.55(-2.5)$ & $-0.25(-3.0)$ & $-81.6(-3.8)$ \\
\hline HPA & $-0.000(-0.0)$ & $0.009(-3.8)$ & $0.23(-0.9)$ & $-0.08(-0.6)$ & $12.4(-0.7)$ \\
\hline \multicolumn{6}{|c|}{ Secreted in hypoxia compared to cell extracts in hypoxia ${ }^{\mathbf{d}}$} \\
\hline up-regulated & $0.014(-2.8)$ & $-0.003(-0.2)$ & $0.71(-1.5)$ & $0.33(-1.1)$ & $42.2(-0.7)$ \\
\hline down-regulated & $0.003(-0.3)$ & $-0.012(-1.5)$ & $0.91(-3.1)$ & $0.49(-2.0)$ & $69.4(-1.6)$ \\
\hline
\end{tabular}

a. Phylostrata from ref. [240]. b. Phylostrata based on gene ages from ref. [241]. c. Differences calculated as (mean of median values for up-regulated proteins in each dataset) - (mean of median values for down-regulated proteins in each dataset), except phylostrata, where mean values for upand down-regulated proteins in each dataset were used. The phylostrata calculations only include datasets for human proteins. $p$-values were calculated with the paired Student's $t$-test by using $R$ function "t.test" [242]. d. Differences calculated as [mean of median values for (up- or down-)regulated proteins secreted in hypoxia] - [mean of median values for (up-or down-)regulated proteins in cell extracts in hypoxia]. $p$-values were calculated with the unpaired Student's $t$-test.

Except for prostate cancer, both pan-cancer datasets exhibit a positive $\Delta n_{\mathrm{H}_{2} \mathrm{O}}$ for the cancer types for which differential expression data were compiled in this study (color-coded circles in Fig. 3). Differential gene expression for all cancer types taken together corresponds to significantly more reduced proteins (Table 2, column $\Delta Z_{C}$ ), but this is not evident in the HPA proteomics datasets. In a pairwise comparison of transcriptomic and proteomic datasets for cancer types, there is very little correlation in $Z_{\mathrm{C}}$ of proteins and even less in $\Delta n_{\mathrm{H}_{2} \mathrm{O}}$ (Fig. S2). It is therefore remarkable that both the pan-cancer transcriptomic and proteomic datasets have a strong visible and statistically significant trend toward higher hydration state of the associated proteins (Table 2, column $\Delta n_{\mathrm{H}_{2} \mathrm{O}}$ ). This could be an indication of an underlying genetic and biochemical tendency in cancer for increased expression of proteins with higher hydration state, despite the well-known overall weak correlation between gene and protein expression levels in cancer and other cells [250,251].

A thermodynamic mass-action hypothesis, i.e. that the nominally reducing effects of hypoxia in tumors should in general lead to greater expression of more reduced proteins, is not supported by the distribution of positive and negative $\Delta Z_{C}$ in the analysis of the HPA datasets. Therefore, a biological explanation is needed. It may be helpful to consider differences in the chemical composition of proteins in different subcellular locations. Membrane and extracellular proteins in yeast are relatively reduced and oxidized, respectively [237]. Similarly, stoichiogenomic analysis of the proteomes of twelve eukaryotic organisms indicates that extracellular proteins have a relatively low hydrogen content [252], which would tend to increase the average carbon oxidation state. Furthermore, up-regulated proteins that are secreted in hypoxia are more oxidized than their counterparts in cell extracts (Table 2). Given 
A

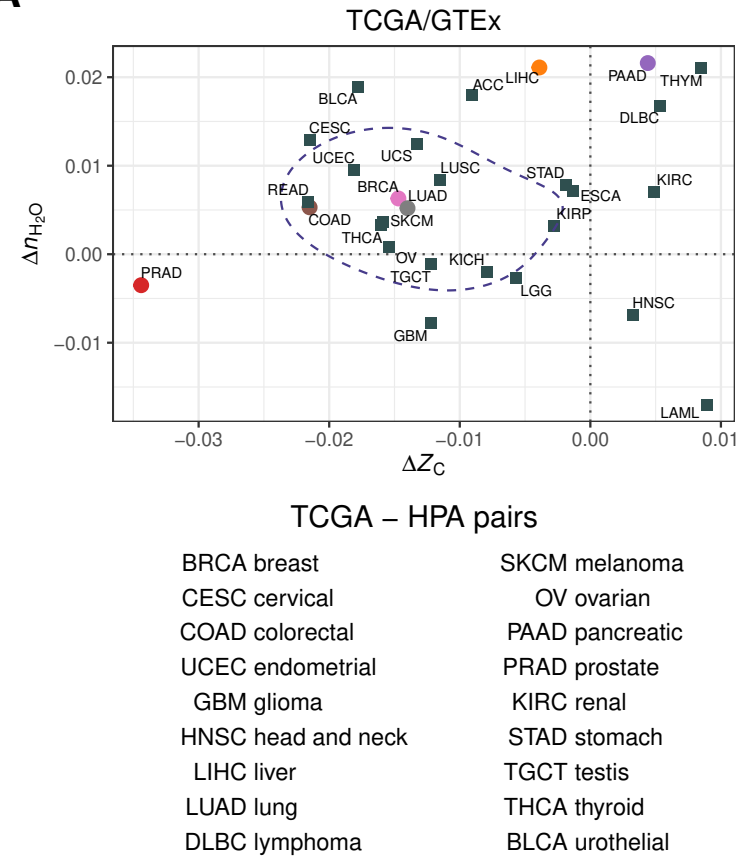

B

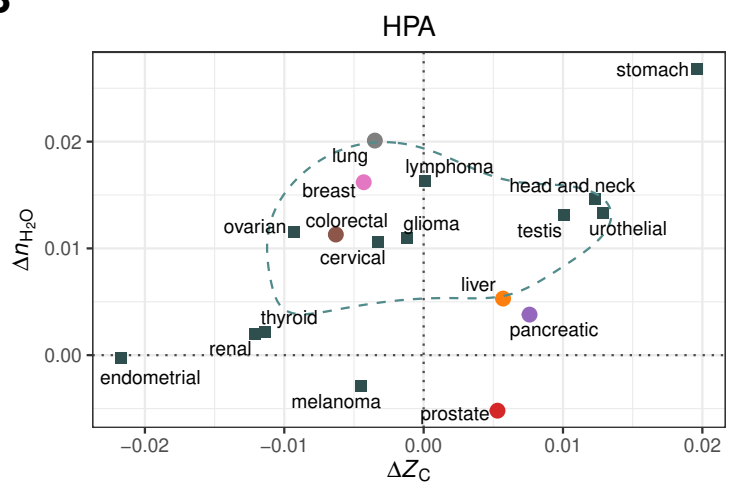

C

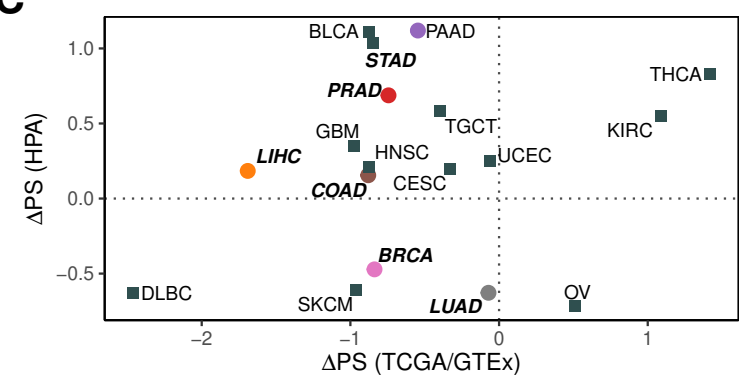

Figure 3. Changes in chemical composition and phylostrata for differentially regulated proteins associated with large-scale transcriptomics and protein antibody studies. (A) Proteins coded by differentially expressed genes between normal tissue (GTEx) and cancer (TCGA). Abbreviations for cancer types are listed in Table S2 (from ref. [243]). (B) Differentially expressed proteins in the Human Protein Atlas [244]. Dashed lines in panels A and B indicate the 50\% credible region for highest probability density. (C) Mean differences of phylostrata (PS, from ref. [240]) for differentially expressed genes (TCGA/GTEx) and genes coding for differentially expressed proteins (HPA). The figure legend shows the TCGA-HPA pairings used for this plot. Color-coded circles represent cancer types with proteomic data compiled in this study (see Fig. 2) and bold italic labels indicate cancer types in the study of Trigos et al. [240]. See Figs. S17-S18 for $\Delta$ PS calculated for all TCGA and HPA datasets.

these general subcellular differences, it is interesting that tissues found by Uhlén et al. [244] to be enriched in membrane proteins (brain and kidney) host cancers with negative values of $\Delta Z_{C}$ (glioma and renal, respectively), while tissues with high levels of proteins known to be secreted (pancreas) or enriched in the transcripts of secreted proteins (liver, stomach) host cancers characterized by positive values of $\Delta Z_{C}$. These patterns seem to imply that the normal enrichment of subcellular protein classes in different tissue types could be magnified in cancer.

It is also informative to compare the compositional metrics with experimental measurements of the hydration status in different types of cancer. For instance, NMR $\mathrm{T}_{1}$ relaxation times are correlated with the early stages of progression of pancreatic ductal adenocarcinoma in mice, but not later stages; this is likely a consequence of increased water and protein content in the early stages [253]. This stage-specific variation of water content may help explain why the range of $\Delta n_{\mathrm{H}_{2} \mathrm{O}}$ of proteins in pancreatic cancer is closer to zero, compared to other cancer types (Figs. 2C, 3B). In another study, optical measurements of gliomas in rats in the spectral range 350-1800 nm were used to infer increased water content in early stages, but decreased amounts in advanced stages, in conjunction with the formation of necrotic regions in the tumor [254]. This appears to be consistent with the small decrease in $\Delta n_{\mathrm{H}_{2} \mathrm{O}}$ between LGG (brain lower grade glioma) and GMB (glioblastoma multiforme) in the TCGA dataset (Fig. $3 A$ ), but it is not possible to observe this trend in the HPA dataset, which only represents a single glioma category with positive $\Delta n_{\mathrm{H}_{2} \mathrm{O}}$ (Fig. 3B). 
A

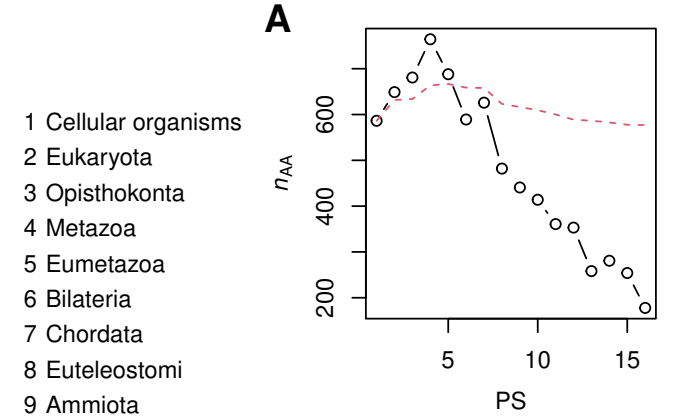

10 Mammalia

11 Theria

12 Eutheria

13 Euarchontoglires

14 Catarrhini

15 Homininae

16 Homo sapiens
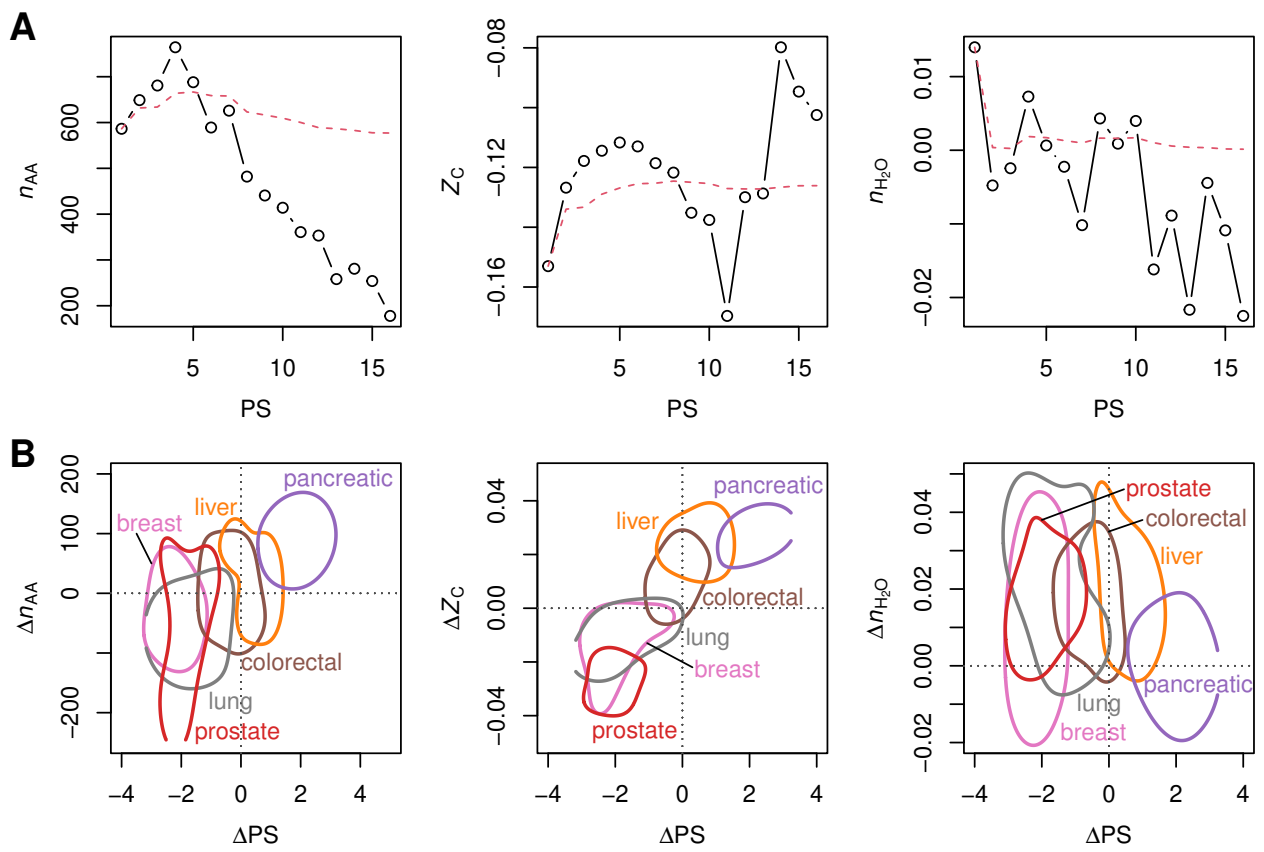

Figure 4. Compositional analysis of proteins using phylostrata given by Trigos et al. [240]. (A) Mean values of $n_{\mathrm{AA}}, Z_{\mathrm{C}}$, and $n_{\mathrm{H}_{2} \mathrm{O}}$ of proteins for all protein-coding genes in each phylostratum (PS). The points stand for the mean values for individual phylostrata, and the red line indicates the cumulative mean starting from PS 1. (B) 50\% credible regions for mean differences of PS plotted against median differences of $n_{\mathrm{AA}}, \mathrm{Z}_{\mathrm{C}}$, and $n_{\mathrm{H}_{2} \mathrm{O}}$ for the six cancer types for which differential expression datasets were compiled in this study. Positive values of $\triangle \mathrm{PS}$ indicate up-regulation of proteins coded by younger genes.

Compared to other cancer types, prostate cancer has distinct trends in the chemical composition of differentially expressed proteins. The negative $\Delta n_{\mathrm{H}_{2} \mathrm{O}}$ of proteins for prostate cancer in the TCGA and HPA datasets (Fig. 3) could be associated with the lower water content of prostate cancer than surrounding normal tissue, as reported in one study using near infrared spectroscopy [255]. However, for unknown reasons this trend is not apparent in the compiled proteomic datasets (Fig. 2B). Furthermore, the highly negative $\Delta Z_{C}$ of the proteins in the compiled proteomic datasets (Fig. $2 B$ ) and those coded by differentially expressed genes in prostate cancer (Fig. $3 A$ ) might somehow be related to the hypoxic characteristics of normal prostate tissue [256] and the unusual metabolic profile of prostate cancer, including de novo lipid synthesis [257] and associated impacts on cellular redox balance [258].

\subsection{Relations between Phylostrata, Chemical Composition, and Protein Length}

Several studies have linked gene expression in cancer to phylogenetically earlier genes [240,259]. The phylostratigraphic analysis used in these studies assigns ages of genes based on the latest common ancestor whose descendants have all the computationally detected homologs of that gene. To analyze the evolutionary trends of oxidation and hydration state of proteins, I used 16 phylostrata (PS) for human protein-coding genes given by Trigos et al. [240]. Using average values for proteins coded by genes in each phylostratum, Fig. $4 A$ shows an initial rise in protein length, leading up to Eukaryota, which is consistent with earlier reports that median protein length is greater in eukaryotes than prokaryotes [260]. The decrease of protein length in later phylostrata is likely an artifact of BLAST-based homology searches [261].

Fig. $4 A$ also shows distinct evolutionary patterns of oxidation state and hydration state of proteins. $Z_{C}$ forms a strikingly smooth hump between PS 1 and 11 then increases rapidly to the maximum at PS 14 , followed by a smaller decline to Homo sapiens. $n_{\mathrm{H}_{2} \mathrm{O}}$ shows an overall decrease through time, but exhibits considerable local variation. 
Trigos et al. [240] used RNAseq gene expression levels from TCGA for cancer and normal tissue as weights to calculate the transcriptome age index (TAI). The TAI was lower for the seven considered cancer types (LUAD, LUSC, BRCA, PRAD, LIHC, COAD, STAD; see Table S2 for definitions of abbreviations) compared to normal tissue, indicating generally higher expression of older genes. I used a different calculation, where $\Delta \mathrm{PS}$ represents non-weighted differences between the means for up- and down-expressed genes, and obtained negative values for the same cancer types using the TCGA/GTEx data (see Fig. 3C for selected cancer types that are paired between TCGA and HPA and Fig. S16 for all TCGA cancer types for which differential gene expression data are available from GEPIA2, including LUSC). Therefore, in agreement with Trigos et al. [240], most cancer transcriptomes are characterized by higher expression of older genes $(\Delta \mathrm{PS}<0)$. However, analysis of the HPA datasets shows that many proteomes exhibit younger ages of the corresponding genes ( $\triangle P S>0)$ (Fig. $3 C$ ). Taken together, the negative differences for transcriptomes are more statistically significant (Table 1 ). The positive $\triangle \mathrm{PS}$ for kidney renal clear cell carcinoma (KIRC) in both datasets (Fig. 3C), which was not analyzed by Trigos et al. [240], is consistent with the large enrichment of vertebrate genes in this cancer type [259]. The agreement with previous work suggests that $\Delta \mathrm{PS}$ is a reasonable metric for comparing gene ages in different cancer types.

The positive association between $\Delta \mathrm{PS}$ and protein length $\left(\Delta n_{\mathrm{AA}}\right)$ for differentially expressed proteins in cancer (Fig. $4 B$ ) implies that the corresponding genes are mostly present in Trigos PS 1 (cellular organisms) to 4 (metazoa), which are characterized by a smoothly increasing protein length (Fig. 4A). This agrees with previous studies wherein the differentially expressed genes in cancer were shown to consist for the most part of genes originating from the unicellular-multicellular transition $[240,259]$. It follows that ages inferred for cancer-related genes are not greatly affected by the artifacts that are likely present in later phylostrata assignments. To gather more evidence, I also used phylostrata corresponding to eight gene ages reported by Liebeskind et al. [241] based on consensus tables for different age-estimation algorithms. Note that the Liebeskind ages have three steps between cellular organisms and Eukaryota, providing a greater resolution in earlier evolution, and stop at Mammalia, which corresponds to Trigos PS 10. Keeping in mind the different resolutions and scales of the Trigos and Liebeskind gene ages, the two datasets show similar maxima for $Z_{C}$ and protein length near Eumetazoa (or Opisthokonta, which is not one of the Trigos phylostrata), and an overall decrease of $n_{\mathrm{H}_{2} \mathrm{O}}$ during evolution (Figs. $4 A$ and S3).

A positive association between $\Delta \mathrm{PS}$ and $\Delta Z_{\mathrm{C}}$ for differentially expressed proteins in cancer would be expected based on the continually increasing $Z_{C}$ for phylostrata $1-4$ shown in Fig. $4 A$. Although the TCGA datasets exhibit a weak negative correlation between $\Delta P S$ and $\Delta Z_{C}$, the correlation is positive and somewhat stronger for the HPA datasets (Fig. S4). Similarly, a positive association between $\Delta \mathrm{PS}$ and $\Delta Z_{\mathrm{C}}$ is visible for the compiled proteomic datasets in Fig. $4 B$. It follows that differences in evolutionary ages of cancer-associated genes may help explain some of the wide variability of oxidation state of differentially expressed proteins found for different cancer types. However, the hydration state of the same proteins is largely independent of ages of the corresponding genes (Fig. $4 B$ ), and the magnitude of $\Delta n_{\mathrm{H}_{2} \mathrm{O}}$ is larger in cancer (from 0.01 to 0.02 ; Table 2) than the cumulative difference between PS 1 and 4 (ca. 0.01; Fig. 4A), so something else is needed to account for the increased hydration state of proteins in cancer.

\section{Discussion}

The evolutionary trends inferred from phylostrata may help to rationalize some features of differential expression of proteins in cancer. For instance, despite the hypoxic nature of tumors, previous authors did not find significantly lower oxygen contents of proteins in glioma and stomach cancer compared to normal tissue $[262,263]$. Likewise, in this study a range of differences in carbon oxidation state was documented, from very negative values for prostate cancer to positive values for colorectal, pancreatic, and liver cancer. Across these cancer types, there is a close association between $\Delta Z_{C}$ and $\Delta$ PS (Fig. $4 B$ ). Unlike the proteomic data, pan-cancer transcriptomes show higher expression 
of generally older genes that also code for more reduced proteins (Fig. $3 A$ and $C$ ), so the genetic connection between the chemical compositions of proteins and tumor hypoxia appears to be shaped more by evolutionary trends than by physicochemical constraints.

It would be fruitful to compare the current results for biomolecular oxidation state with oxygen and redox measurements for tumors [13,14], but systematic measurements across tumor types may not be available. The results can also be compared with hypoxia scores computed from gene expression data [264], with the caveat that they are not physicochemical measurements. Median hypoxia scores reported for 19 tumor types [265] are not correlated with differences of $Z_{\mathrm{C}}$ or $n_{\mathrm{H}_{2} \mathrm{O}}$ from TCGA or HPA data (Fig. S5, but note the weak positive correlation between hypoxia score and $\Delta n_{\mathrm{H}_{2} \mathrm{O}}$ for the HPA datasets). In general, therefore, gene expression-based hypoxia scores and chemical compositions of proteins likely reflect distinct physiological processes. Nevertheless, the significantly negative $\Delta Z_{C}$ on average for the TCGA data (Fig. 3A; Table 2) raises the possibility that the chemical composition of differentially expressed proteins at the transcriptional level, but for some reason not translational level, reflects the hypoxic conditions that occur in many tumor microenvironments.

It is also somewhat surprising that hypoxia in cell culture generally does not induce the up-regulation of more reduced proteins (Table 2). The frequent downregulation of mitochondrial proteins in hypoxia [36,39] provides a possible explanation. Not only are mitochondria strongly anoxic subcellular compartments [266], but their proteins also have a relatively low $Z_{C}$ compared to other subcellular fractions including the cytoplasm and nucleus $[237,267]$, so their downregulation would tend to produce more oxidized proteins at the whole-cell level. More proteomic data for subcellular fractions are needed to better understand the overall cellular response and perhaps also what causes proteins secreted in hypoxia to be relatively oxidized (Table 2).

In marked contrast to the diverse trends of oxidation state, most cancer types are characterized by a higher stoichiometric hydration state of proteins at both the transcriptional and translational levels. These results indicate that water is consumed as a reactant when the differential expression of proteins in cancer is represented theoretically as an overall chemical reaction. This observation represents a bridge between proteomic data and experimental observations of elevated water content in tumors $[6,268,269]$, and provides a novel line of evidence supporting the hypothesis of a primary role for elevated cellular hydration in cancer [8].

Further developments of genome-scale metabolic and macromolecular expression models [272] should be pursued to generate more precise estimates of the net water and oxygen demands for amino acid biosynthesis, uptake and incorporation into proteomes in different conditions. Nevertheless, the power of a compositional analysis of chemical formulas should not be overlooked. The quantile distributions plotted in Fig. $5 \mathrm{~A}$ and $B$ provide a striking example, showing minor differences in $Z_{C}$, but large positive differences of $n_{\mathrm{H}_{2} \mathrm{O}}$ for proteins coded by up-regulated genes compared to those coded by down-regulated genes in a "common aneuploidy gene expression" dataset (CAGE) [270]. The increases of $n_{\mathrm{H}_{2} \mathrm{O}}$ occur over a large majority of quantile points; in other words, the differences in this case exhibit nearly stochastic ordering, and therefore could arise from globally significant compositional biases [273]. Although the previous plots only show the median differences for many other datasets, it is possible to compute the quantile distributions for each dataset using the data deposited along with this paper (Section 4.5).

Aneuploidy, or changes in chromosome number, is common in cancer cells [1], and Tsai et al. [270] found that gene expression patterns in aneuploid yeast cells are similar to those in normal yeast cells exposed to hypoosmotic (that is, more dilute, the opposite of hyperosmotic) conditions. Compositional analysis of data for gene expression in stressed yeast cells [271] indeed shows that the proteins coded by the differentially expressed genes in hypoosmotic conditions have higher $n_{\mathrm{H}_{2} \mathrm{O}}$, and those in hyperosmotic conditions have lower $n_{\mathrm{H}_{2} \mathrm{O}}$ (Fig. $5 \mathrm{C}$ and $D$ and Fig. S19). The large increases in $n_{\mathrm{H}_{2} \mathrm{O}}$ of the proteins coded by differentially expressed genes in both aneuploidy and hypoosmotic conditions suggests an possible underlying physicochemical factor: the chemical compositions of the proteins may reflect higher water activity in relatively dilute conditions. Unfortunately, gene or protein 

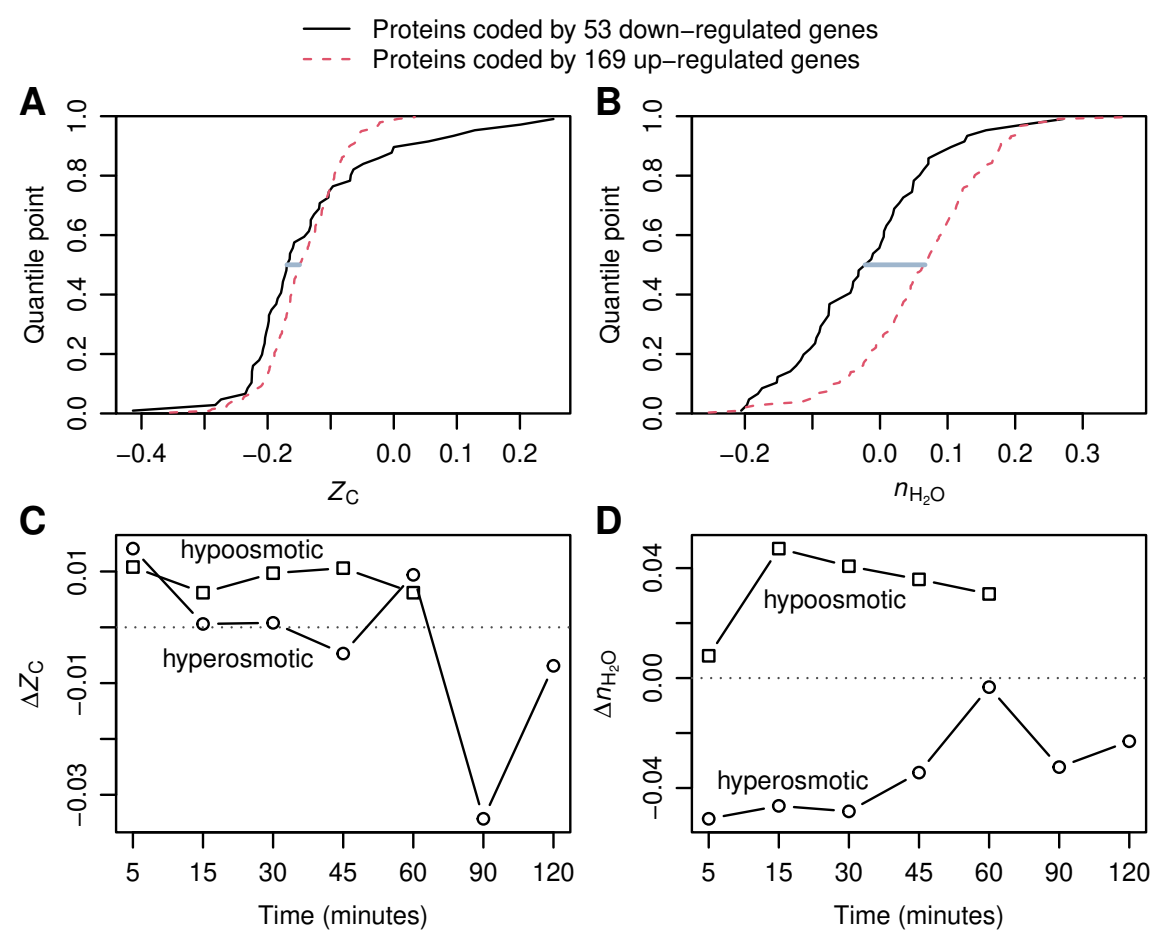

Figure 5. Quantile distributions of $(\mathbf{A}) Z_{\mathrm{C}}$ and (B) $n_{\mathrm{H}_{2} \mathrm{O}}$ for proteins coded by differentially expressed genes in aneuploid yeast cells compared to haploid cells [270]. The median differences are indicated by the horizontal lines drawn at the 0.5 quantile point. Median differences of (C) $\Delta Z_{C}$ and (D) $\Delta n_{\mathrm{H}_{2} \mathrm{O}}$ between groups of proteins coded by up- and down-regulated genes in yeast cells exposed to hyperosmotic shock (sudden shift from 0 to $1 \mathrm{M}$ sorbitol) or hypoosmotic shock (growth at $1 \mathrm{M}$ sorbitol followed by centrifugation to collect cells and resuspension in medium with $0 \mathrm{M}$ sorbitol) [271].

expression data for hypo- and hyperosmotic experiments have not been reported for cancer cells, so it is currently unknown whether they show a similar response.

The claim that differences of stoichiometric hydration state of proteins can be used as an indicator of physicochemical conditions of cells is strengthened by compositional analysis of proteomic data for cell culture in controlled laboratory experiments. In response to changing salinities, the interiors of most cells must be at least isosmotic with the environment to maintain a physiological water content [274]. Nevertheless, hyperosmotic conditions still exert a dehydrating effect on cell interiors, as shown by experiments with Escherichia coli in which the water content of cells grown in hyperosmotic $\mathrm{NaCl}$ solutions is substantially lowered [275]. Likewise, I found that the hydration state of differentially expressed proteins often decreases in $\mathrm{NaCl}$-induced hyperosmotic stress in non-cancer eukaryotic cells (Fig. $2 \mathrm{C}$ and Table 2). A similar trend is visible in proteomics data for bacterial cells, but the effect is not very large [18]. On the other hand, experiments with eukaryotic cells in high-glucose media, which are often used to model the effects of hyperglycemia in diabetes and are also recognized for generating hyperosmotic conditions [85], show a larger average decrease in hydration state of proteins (Table 2). The present results support the hypothesis that osmotically induced dehydration provides a thermodynamic drive for the preferential expression of proteins with lower stoichiometric hydration state.

An initially unexpected finding is that the hydration state of proteins is substantially lower in $3 \mathrm{D}$ culture, including spheroids and aggregates, compared to traditional 2D culture in monolayers (Fig. 2A; see also Fig. S9). This finding might be linked with the less liquid-like state of the cytoplasm in $3 \mathrm{D}$ culture [276]. These results are also concordant with metagenomes of particle-sized fractions compared to free-living microbes in river and marine samples; the former, which are more likely to harbor multicellular communities, are associated with lower $n_{\mathrm{H}_{2} \mathrm{O}}$ of the coded proteins [18]. Besides 
the strong decrease of $n_{\mathrm{H}_{2} \mathrm{O}}$, up-regulated proteins in 3D culture also tend to be more reduced (Table 2), which might reflect the attainment of hypoxic conditions in the interiors of spheroids $[20,21,277]$.

Mesenchymal stromal cells growing in aggregates proliferate more slowly than those in monolayers under otherwise similar conditions [104]. For tumor spheroids themselves, the proliferation of cells in the core is inhibited in stress clamp experiments, which drives water out of the aggregates [278]. In monolayer cell culture, hyperosmotic conditions slow the proliferation of breast cancer cells [279] and can induce prostate cancer cells cultured at low density to enter a dormant state [280]. In contrast to lower water content, which is a feature of dormant cells [9], cell swelling in hypoosmotic conditions is a proliferative signal [281], and increased total $\mathrm{K}^{+}$and water content accompanies the onset of proliferation in human blood lymphocytes exiting a quiescent state [282]. Complementary to these experimental observations, uncontrolled proliferation is identified as one of the hallmarks of cancer cells [283]. Against this background, the findings in this study of higher $n_{\mathrm{H}_{2} \mathrm{O}}$ for proteins in both cancer and hypoosmotic conditions, together with lower $n_{\mathrm{H}_{2} \mathrm{O}}$ in both hyperosmotic and 3D culture conditions, could represent a new biochemical link in the association between cellular hydration levels and proliferation.

\section{Materials and Methods}

\subsection{Proteomics Datasets}

Differential protein expression data reported for any proteomics method applied to cell culture experiments and cancer compared to normal tissue were located through literature searches. Several review articles were also consulted in order to locate experimental data for breast cancer [284], lung cancer [285,286], and 3D cell culture [277]. In general, datasets were selected that have a minimum of 30 up-regulated and 30 down-regulated proteins in order to reduce random variation associated with small sample sizes, but smaller datasets (at least ca. 20 up-regulated and 20 down-regulated proteins) were included for hyperosmotic stress, secreted proteins in hypoxia, lung cancer, and prostate cancer due to limited availability of data.

Previous compilations for hypoxia and colorectal and pancreatic cancer [19] were updated in this study using more recently located datasets. Datasets related to prognosis, conditioned media, stromal samples, and adenoma were removed from the updated compilation for colorectal cancer. In addition, datasets for cellular and secreted proteins in hypoxia were considered separately, and datasets for reoxygenation after hypoxia were excluded. The previous compilation of data for hyperosmotic stress [19] was also expanded in this study, but a fish gill proteome and two transcriptomic datasets were excluded, and high-salt and high-glucose datasets were analyzed separately.

Lists of significantly differentially expressed proteins were taken directly from the original publications if possible. In cases of datasets where mass spectrometric data but not lists of differentially expressed proteins were reported, quantile normalization using function "normalize.quantiles" in the R package preprocessCore [287] was performed on the intensities or peak areas in order to obtain normalized values that were used to calculate expression ratios. Where needed, reported protein or gene identifiers were converted to UniProt IDs using the UniProt mapping tool [288]. Protein sequences downloaded from UniProt were used to generate amino acid compositions using function "read.fasta" in the R package CHNOSZ [289]. The canonical protein sequences in UniProt were used, unless isoforms were identified in the data sources. Details of additional processing steps are given with Figs. S6-S16.

\subsection{Differential Expression from Pan-Cancer Datasets}

Immunohistochemistry-based expression profiles of proteins in normal tissue and pathology samples were downloaded from the Human Protein Atlas version 19 [244,249]. Pathology and normal tissue datasets were paired based on information from the HPA web site [290]: breast cancer / breast; cervical cancer / cervix, uterine; colorectal cancer / colon; endometrial cancer / endometrium 1; 
glioma / cerebral cortex; head and neck cancer / salivary gland; liver cancer / liver; lung cancer / lung; lymphoma / lymph node; melanoma / skin 1; skin cancer / skin 1; ovarian cancer / ovary; pancreatic cancer / pancreas; prostate cancer / prostate; renal cancer / kidney; stomach cancer / stomach 1; testis cancer / testis; thyroid cancer / thyroid gland; urothelial cancer / urinary bladder. Antibody staining intensities were converted to a semi-quantitative scale (not detected: 0 , low: 1 , medium: 3, high: 5). The expression level score for each protein was calculated by averaging the score for available samples, including "not detected" but excluding unavailable (NA) observations, and, for normal tissues, observations in all available cell types. Differences in expression score between normal and cancer $\geq 2.5$ or $\leq-2.5$ were considered to be differentially expressed proteins.

Differential gene expression values were obtained using version 2 of the Gene Expression Profiling Interactive Analysis web server (GEPIA2) [245] with default settings (ANOVA, $\log _{2}$ fold change cutoff $=1, q$-value cutoff $=0.01)$. Pairings between source datasets for cancer $($ TCGA) and normal tissue (GTEx), as described on the GEPIA2 website [291] are: ACC / adrenal gland; BLCA / bladder; BRCA / breast; CESC / cervix uteri; COAD / colon; DLBC / blood; ESCA / esophagus; GBM / brain; KICH / kidney; KIRC / kidney; KIRP / kidney; LAML / bone marrow; LGG / brain; LIHC / liver; LUAD / lung; LUSC / lung; OV / ovary; PAAD / pancreas; PRAD / prostate; READ / colon; SKCM/ skin; STAD / stomach; TGCT / testis; THCA / thyroid; THYM / blood; UCEC / uterus; UCS / uterus. Gene expression data for both tumor and normal tissue for HNSC are from TCGA. Differential expression data were not available on GEPIA2 for five other cancer types in TCGA (CHOL, MESO, PCPG, SARC, UVM). Ensembl Gene IDs used in HPA and GEPIA were converted to UniProt accession numbers using the UniProt mapping tool [288].

\subsection{Compositional Metrics}

Values of average oxidation state of carbon $\left(Z_{C}\right)$ of amino acids (Table 1$)$ were calculated from the chemical formulas of the amino acids $[236,237]$. Values for $Z_{C}$ of proteins were computed by combining the amino acid compositions of proteins with $Z_{C}$ of amino acids and also weighting by carbon number [18]. That is, $Z_{\mathrm{C}}=\Sigma Z_{\mathrm{C}, i} n_{i} n_{\mathrm{C}, i} / \Sigma n_{i} n_{\mathrm{C}, i}$, where the summation is over $i=1 . .20$ amino acids and $Z_{\mathrm{C}, i}$ $n_{i}$, and $n_{C, i}$ are the carbon oxidation state, frequency in the protein sequence, and number of carbon atoms of the $i$ th amino acid, respectively.

Values of stoichiometric hydration state $\left(n_{\mathrm{H}_{2} \mathrm{O}}\right)$ for amino acids (Table 1$)$ were calculated using the rQEC derivation described by Dick et al. [18]. Briefly, the numbers of $\mathrm{H}_{2} \mathrm{O}$ in theoretical formation reactions for the 20 amino acid residues were obtained by projecting the elemental compositions of the amino acids into the basis species glutamine, glutamic acid, cysteine, $\mathrm{H}_{2} \mathrm{O}$, and $\mathrm{O}_{2}(\mathrm{QEC}$ basis species; see Table $\mathrm{S} 1$ and Fig. S1A). The stoichiometric hydration state was obtained by calculating the residuals of a linear model fit to $n_{\mathrm{H}_{2} \mathrm{O}}$ and $Z_{\mathrm{C}}$ for the amino acid residues, then subtracting a constant from the residuals to make the mean per-residue value for all human proteins equal to zero. The residual analysis ensures that there is no correlation between $n_{\mathrm{H}_{2} \mathrm{O}}$ and $Z_{\mathrm{C}}$ of amino acids (Fig. $\mathrm{S} 1 B$ ). To compute per-residue values for proteins, the values of $n_{\mathrm{H}_{2} \mathrm{O}}$ for amino acid residues from Table 1 were combined with the amino acid compositions of the proteins. That is, $n_{\mathrm{H}_{2} \mathrm{O}}=\Sigma n_{\mathrm{H}_{2} \mathrm{O}, i} n_{i} /$ $\Sigma n_{i}$, where $n_{\mathrm{H}_{2} \mathrm{O}, i}$ and $n_{i}$ are the stoichiometric hydration state and frequency of the $i$ th amino acid residue, respectively. Accordingly, $\Delta n_{\mathrm{H}_{2} \mathrm{O}}=0.01$ corresponds to a difference of approximately 3 water molecules in the theoretical formation reaction of a typical 300-residue protein.

\subsection{Phylostrata}

Phylostrata were obtained from the supporting information of Trigos et al. [240] and the "main_HUMAN.csv" file of Liebeskind et al. [241,292]. Liebeskind et al. did not give phylostrata numbers, so phylostrata 1-8 were assigned here based on the names in the "modeAge" column of the source file (see Fig. S3). The Ensembl gene identifiers in the Trigos dataset were converted to UniProt accession numbers [288]; in the case of duplicate UniProt accession numbers, the first matching phylostratum was used. 


\subsection{Data deposition}

The compiled differential expression data are provided in the canprot $\mathrm{R}$ package, version 1.0.0 (https://cran.r-project.org/package=canprot). Other data used for this paper are in the "canH2O", "aneuploidy", and "yeast_stress" directories of the JMDplots package, version 1.2.2 (https://github.com/jedick/JMDplots). The specified versions of both of these packages are also deposited on Zenodo [293,294]. Figs. S6-S16 are derived from the vignettes in the canprot package, and the code for the remaining figures and Tables 2 and $\mathrm{S} 1$ is in the JMDplots package; the "canH2O" vignette in this package has the function calls used to make the figures and tables.

Supplementary Materials: Figures S1-S19, Tables S1-S2.

Funding: This research received no external funding.

Acknowledgments: I am grateful to Alex Greenhough, Youngsoo Kim, Ming-Chih Lai, and Gordana Vunjak-Novakovic for providing data files. The results shown here are in part based upon data generated by the TCGA Research Network (https://www.cancer.gov/tcga) and the Human Protein Atlas (https://www.proteinatlas.org).

Conflicts of Interest: The author declares no conflict of interest.

\section{References}

1. Vogelstein, B.; Papadopoulos, N.; Velculescu, V.E.; Zhou, S.; Diaz, L.A.; Kinzler, K.W. Cancer genome landscapes. Science 2013, 339, 1546-1558. doi:10.1126/science.1235122.

2. Gillies, R.J.; Robey, I.; Gatenby, R.A. Causes and consequences of increased glucose metabolism of cancers. Journal of Nuclear Medicine 2008, 49, 24S-42S. doi:10.2967/jnumed.107.047258.

3. Höckel, M.; Vaupel, P. Tumor hypoxia: Definitions and current clinical, biologic, and molecular aspects. Journal of the National Cancer Institute 2001, 93, 266-276. doi:10.1093/jnci/93.4.266.

4. Winzler, R.J. The chemistry of cancer tissue. In The Physiopathology of Cancer, 2nd ed.; Homburger, F., Ed.; Hoeber-Harper: New York, 1959; pp. 686-706.

5. Downing, J.E.; Christopherson, W.M.; Broghamer, W.L. Nuclear water content during carcinogenesis. Cancer 1962, 15, 1176-1180. doi:10.1002/1097-0142(196211/12)15:6<1176::AID-CNCR2820150614>3.0.CO;2-F.

6. Surmacki, J.; Musial, J.; Kordek, R.; Abramczyk, H. Raman imaging at biological interfaces: Applications in breast cancer diagnosis. Molecular Cancer 2013, 12, 48. doi:10.1186/1476-4598-12-48.

7. Barroso, E.M.; Smits, R.W.H.; Bakker Schut, T.C.; ten Hove, I.; Hardillo, J.A.; Wolvius, E.B.; Baatenburg de Jong, R.J.; Koljenović, S.; Puppels, G.J. Discrimination between oral cancer and healthy tissue based on water content determined by Raman spectroscopy. Analytical Chemistry 2015, 87, 2419-2426. doi:10.1021/ac504362y.

8. McIntyre, G.I. Cell hydration as the primary factor in carcinogenesis: A unifying concept. Medical Hypotheses 2006, 66, 518-526. doi:10.1016/j.mehy.2005.09.022.

9. Munder, M.C.; Midtvedt, D.; Franzmann, T.; Nüske, E.; Otto, O.; Herbig, M.; Ulbricht, E.; Müller, P.; Taubenberger, A.; Maharana, S.; Malinovska, L.; Richter, D.; Guck, J.; Zaburdaev, V.; Alberti, S. A $\mathrm{pH}$-driven transition of the cytoplasm from a fluid- to a solid-like state promotes entry into dormancy. eLife 2016, 5, e09347. doi:10.7554/eLife.09347.

10. Morowitz, H.J. A theory of biochemical organization, metabolic pathways, and evolution. Complexity 1999, 4, 39-53. doi:10.1002/(SICI)1099-0526(199907/08)4:6<39::AID-CPLX8>3.0.CO;2-2.

11. Braakman, R.; Smith, E. The compositional and evolutionary logic of metabolism. Physical Biology 2013, 10, 011001. doi:10.1088/1478-3975/10/1/011001.

12. Filipp, F.V.; Scott, D.A.; Ronai, Z.A.; Osterman, A.L.; Smith, J.W. Reverse TCA cycle flux through isocitrate dehydrogenases 1 and 2 is required for lipogenesis in hypoxic melanoma cells. Pigment Cell \& Melanoma Research 2012, 25, 375-383. doi:10.1111/j.1755-148X.2012.00989.x.

13. Kuppusamy, P.; Afeworki, M.; Shankar, R.A.; Coffin, D.; Krishna, M.C.; Hahn, S.M.; Mitchell, J.B.; Zweier, J.L. In vivo electron paramagnetic resonance imaging of tumor heterogeneity and oxygenation in a murine model. Cancer Research 1998, 58, 1562-1568. https:/ / cancerres.aacrjournals.org/content/58/7/1562. 
14. Hyodo, F.; Davis, R.M.; Hyodo, E.; Matsumoto, S.; Krishna, M.C.; Mitchell, J.B. The relationship between tissue oxygenation and redox status using magnetic resonance imaging. International Journal of Oncology 2012, 41, 2103-2108. doi:10.3892/ijo.2012.1638.

15. Guzy, R.D.; Schumacker, P.T. Oxygen sensing by mitochondria at complex III: The paradox of increased reactive oxygen species during hypoxia. Experimental Physiology 2006, 91, 807-819. doi:10.1113/expphysiol.2006.033506.

16. Häussinger, D.; Lang, F.; Gerok, W. Regulation of cell function by the cellular hydration state. American Journal of Physiology 1994, 267, E343-E355. doi:10.1152/ajpendo.1994.267.3.E343.

17. Nelson, D.M.; Cox, M.M. Lehninger Principles of Biochemistry, 4th ed.; W. H. Freeman and Company: New York, 2005.

18. Dick, J.M.; Yu, M.; Tan, J. Uncovering chemical signatures of salinity gradients through compositional analysis of protein sequences. Biogeosciences Discussions 2020, in review. doi:10.5194/bg-2020-146.

19. Dick, J.M. Chemical composition and the potential for proteomic transformation in cancer, hypoxia, and hyperosmotic stress. PeerJ 2017, 5, e3421. doi:10.7717/peerj.3421.

20. Hirschhaeuser, F.; Menne, H.; Dittfeld, C.; West, J.; Mueller-Klieser, W.; Kunz-Schughart, L.A. Multicellular tumor spheroids: An underestimated tool is catching up again. Journal of Biotechnology 2010, 148, 3-15. doi:10.1016/j.jbiotec.2010.01.012.

21. Baker, B.M.; Chen, C.S. Deconstructing the third dimension - how 3D culture microenvironments alter cellular cues. Journal of Cell Science 2012, 125, 3015-3024. doi:10.1242/jcs.079509.

22. Stockwin, L.H.; Blonder, J.; Bumke, M.A.; Lucas, D.A.; Chan, K.C.; Conrads, T.P.; Issaq, H.J.; Veenstra, T.D.; Newton, D.L.; Rybak, S.M. Proteomic analysis of plasma membrane from hypoxia-adapted malignant melanoma. Journal of Proteome Research 2006, 5, 2996-3007. doi:10.1021/pr0601739.

23. Fuhrmann, D.C.; Wittig, I.; Heide, H.; Dehne, N.; Brüne, B. Chronic hypoxia alters mitochondrial composition in human macrophages. Biochimica et Biophysica Acta (BBA) - Proteins and Proteomics 2013, 1834, 2750-2760. doi:10.1016/j.bbapap.2013.09.023.

24. Ren, Y.; Hao, P.; Dutta, B.; Cheow, E.S.H.; Sim, K.H.; Gan, C.S.; Lim, S.K.; Sze, S.K. Hypoxia modulates A431 cellular pathways association to tumor radioresistance and enhanced migration revealed by comprehensive proteomic and functional studies. Molecular E Cellular Proteomics 2013, 12, 485-498. doi:10.1074/mcp.M112.018325.

25. Villeneuve, L.; Tiede, L.M.; Morsey, B.; Fox, H.S. Quantitative proteomics reveals oxygen-dependent changes in neuronal mitochondria affecting function and sensitivity to rotenone. Journal of Proteome Research 2013, 12, 4599-4606. doi:10.1021/pr400758d.

26. Djidja, M.C.; Chang, J.; Hadjiprocopis, A.; Schmich, F.; Sinclair, J.; Mršnik, M.; Schoof, E.M.; Barker, H.E.; Linding, R.; Jørgensen, C.; Erler, J.T. Identification of hypoxia-regulated proteins using MALDI-mass spectrometry imaging combined with quantitative proteomics. Journal of Proteome Research 2014, 13, 2297-2313. doi:10.1021/pr401056c.

27. Dutta, B.; Yan, R.; Lim, S.K.; Tam, J.P.; Sze, S.K. Quantitative profiling of chromatome dynamics reveals a novel role for HP1BP3 in hypoxia-induced oncogenesis. Molecular E Cellular Proteomics 2014, 13, 3236-3249. doi:10.1074/mcp.M114.038232.

28. Bousquet, P.A.; Sandvik, J.A.; Arntzen, M.Ø.; Jeppesen Edin, N.F.; Christoffersen, S.; Krengel, U.; Pettersen, E.O.; Thiede, B. Hypoxia strongly affects mitochondrial ribosomal proteins and translocases, as shown by quantitative proteomics of HeLa cells. International Journal of Proteomics 2015, 2015, 678527. doi:10.1155/2015/678527.

29. Ho, J.J.D.; Wang, M.; Audas, T.; Kwon, D.; Carlsson, S.; Timpano, S.; Evagelou, S.; Brothers, S.; Gonzalgo, M.; Krieger, J.; Chen, S.; Uniacke, J.; Lee, S. Systemic reprogramming of translation efficiencies on oxygen stimulus. Cell Reports 2016, 14, 1293-1300. doi:10.1016/j.celrep.2016.01.036.

30. Lai, M.C.; Chang, C.M.; Sun, H.S. Hypoxia induces autophagy through translational up-regulation of lysosomal proteins in human colon cancer cells. PLOS One 2016, 11, e0153627. doi:10.1371/journal.pone.0153627.

31. Cosme, J.; Guo, H.; Hadipour-Lakmehsari, S.; Emili, A.; Gramolini, A.O. Hypoxia-induced changes in the fibroblast secretome, exosome, and whole-cell proteome using cultured, cardiac-derived cells isolated from neonatal mice. Journal of Proteome Research 2017, 16, 2836-2847. doi:10.1021/acs.jproteome.7b00144. 
32. Zhang, K.; Xu, P.; Sowers, J.L.; Machuca, D.F.; Mirfattah, B.; Herring, J.; Tang, H.; Chen, Y.; Tian, B.; Brasier, A.R.; Sowers, L.C. Proteome analysis of hypoxic glioblastoma cells reveals sequential metabolic adaptation of one-carbon metabolic pathways. Molecular $\mathcal{E}$ Cellular Proteomics 2017, 16, 1906-1921. doi:10.1074/mcp.RA117.000154.

33. Chen, J.T.; Liu, C.C.; Yu, J.S.; Li, H.H.; Lai, M.C. Integrated omics profiling identifies hypoxia-regulated genes in HCT116 colon cancer cells. Journal of Proteomics 2018, 188, 139-151. doi:10.1016/j.jprot.2018.02.031. 34. Greenhough, A.; Bagley, C.; Heesom, K.J.; Gurevich, D.B.; Gay, D.; Bond, M.; Collard, T.J.; Paraskeva, C.; Martin, P.; Sansom, O.J.; Malik, K.; Williams, A.C. Cancer cell adaptation to hypoxia involves a HIF-GPRC5A-YAP axis. EMBO Molecular Medicine 2018, 10, e8699. doi:10.15252/emmm.201708699.

35. Lee, J.; .; Kim, H.S.; Kim, S.M.; Kim, D.I.; Lee, C.W. Hypoxia upregulates mitotic cyclins which contribute to the multipotency of human mesenchymal stem cells by expanding proliferation lifespan. Molecules and Cells 2018, 41, 207-213. doi:10.14348/molcells.2018.2231.

36. Wobma, H.M.; Tamargo, M.A.; Goeta, S.; Brown, L.M.; Duran-Struuck, R.; Vunjak-Novakovic, G. The influence of hypoxia and IFN- $\gamma$ on the proteome and metabolome of therapeutic mesenchymal stem cells. Biomaterials 2018, 167, 226-234. doi:10.1016/j.biomaterials.2018.03.027.

37. Chachami, G.; Stankovic-Valentin, N.; Karagiota, A.; Basagianni, A.; Plessmann, U.; Urlaub, H.; Melchior, F.; Simos, G. Hypoxia-induced changes in SUMO conjugation affect transcriptional regulation under low oxygen. Molecular \& Cellular Proteomics 2019, 18, 1197-1209. doi:10.1074/mcp.RA119.001401.

38. Gupta, N.; Park, J.E.; Tse, W.; Low, J.K.; Kon, O.L.; McCarthy, N.; Sze, S.K. ERO1 $\alpha$ promotes hypoxic tumor progression and is associated with poor prognosis in pancreatic cancer. Oncotarget 2019, 10, 5970-5982. doi:10.18632/oncotarget.27235.

39. Kugeratski, F.G.; Atkinson, S.J.; Neilson, L.J.; Lilla, S.; Knight, J.R.P.; Serneels, J.; Juin, A.; Ismail, S.; Bryant, D.M.; Markert, E.K.; Machesky, L.M.; Mazzone, M.; Sansom, O.J.; Zanivan, S. Hypoxic cancer-associated fibroblasts increase NCBP2-AS2/HIAR to promote endothelial sprouting through enhanced VEGF signaling. Science Signaling 2019, 12, eaan8247. doi:10.1126/scisignal.aan8247.

40. Li, Q.; Luo, T.; Lu, W.; Yi, X.; Zhao, Z.; Liu, J. Proteomic analysis of human periodontal ligament cells under hypoxia. Proteome Science 2019, 17, 3. doi:10.1186/s12953-019-0151-2.

41. Bush, J.T.; Chan, M.C.; Mohammed, S.; Schofield, C. Quantitative MS-based proteomics comparing the MCF-7 cellular response to hypoxia and a 2-oxoglutarate analogue. ChemBioChem 2020, 21, 1647-1655. doi:10.1002/cbic.201900719.

42. Ross, J.A.; Vissers, J.P.; Nanda, J.; Stewart, G.D.; Husi, H.; Habib, F.K.; Hammond, D.E.; Gethings, L.A. The influence of hypoxia on the prostate cancer proteome. Clinical Chemistry and Laboratory Medicine 2020, 58, 980-993. doi:10.1515/cclm-2019-0626.

43. Song, Z.; Pearce, M.C.; Jiang, Y.; Yang, L.; Goodall, C.; Miranda, C.L.; Milovancev, M.; Bracha, S.; Kolluri, S.K.; Maier, C.S. Delineation of hypoxia-induced proteome shifts in osteosarcoma cells with different metastatic propensities. Scientific Reports 2020, 10, 727. doi:10.1038/s41598-019-56878-x.

44. Blankley, R.T.; Robinson, N.J.; Aplin, J.D.; Crocker, I.P.; Gaskell, S.J.; Whetton, A.D.; Baker, P.N.; Myers, J.E. A gel-free quantitative proteomics analysis of factors released from hypoxic-conditioned placentae. Reproductive Sciences 2010, 17, 247-257. doi:10.1177/1933719109351320.

45. Park, J.E.; Tan, H.S.; Datta, A.; Lai, R.C.; Zhang, H.; Meng, W.; Lim, S.K.; Sze, S.K. Hypoxic tumor cell modulates its microenvironment to enhance angiogenic and metastatic potential by secretion of proteins and exosomes. Molecular E Cellular Proteomics 2010, 9, 1085-1099. doi:10.1074/mcp.M900381-MCP200.

46. de Jong, O.G.; Verhaar, M.C.; Chen, Y.; Vader, P.; Gremmels, H.; Posthuma, G.; Schiffelers, R.M.; Gucek, M.; van Balkom, B.W. Cellular stress conditions are reflected in the protein and RNA content of endothelial cell-derived exosomes. Journal of Extracellular Vesicles 2012, 1, 18396. doi:10.3402/jev.v1i0.18396.

47. Salomon, C.; Kobayashi, M.; Ashman, K.; Sobrevia, L.; Mitchell, M.D.; Rice, G.E. Hypoxia-induced changes in the bioactivity of cytotrophoblast-derived exosomes. PLOS One 2013, 8, e79636. doi:10.1371/journal.pone.0079636.

48. Salomon, C.; Ryan, J.; Sobrevia, L.; Kobayashi, M.; Ashman, K.; Mitchell, M.; Rice, G.E. Exosomal signaling during hypoxia mediates microvascular endothelial cell migration and vasculogenesis. PLOS One 2013, 8, e68451. doi:10.1371/journal.pone.0068451. 
49. Li, X.; Ren, Y.; Sorokin, V.; Poh, K.K.; Ho, H.H.; Lee, C.N.; de Kleijn, D.; Lim, S.K.; Tam, J.P.; Sze, S.K. Quantitative profiling of the rat heart myoblast secretome reveals differential responses to hypoxia and re-oxygenation stress. Journal of Proteomics 2014, 98, 138-149. doi:10.1016/j.jprot.2013.12.025.

50. Yoon, J.H.; Kim, J.; Kim, K.L.; Kim, D.H.; Jung, S.J.; Lee, H.; Ghim, J.; Kim, D.; Park, J.B.; Ryu, S.H.; Lee, T.G. Proteomic analysis of hypoxia-induced U373MG glioma secretome reveals novel hypoxia-dependent migration factors. Proteomics 2014, 14, 1494-1502. doi:10.1002/pmic.201300554.

51. Cox, T.R.; Rumney, R.M.H.; Schoof, E.M.; Perryman, L.; Høye, A.M.; Agrawal, A.; Bird, D.; Latif, N.A.; Forrest, H.; Evans, H.R.; Huggins, I.D.; Lang, G.; Linding, R.; Gartland, A.; Erler, J.T. The hypoxic cancer secretome induces pre-metastatic bone lesions through lysyl oxidase. Nature 2015, 522, 106-110. doi:10.1038/nature14492.

52. Ramteke, A.; Ting, H.; Agarwal, C.; Mateen, S.; Somasagara, R.; Hussain, A.; Graner, M.; Frederick, B.; Agarwal, R.; Deep, G. Exosomes secreted under hypoxia enhance invasiveness and stemness of prostate cancer cells by targeting adherens junction molecules. Molecular Carcinogenesis 2015, 54, 554-565. doi:10.1002/mc.22124.

53. Riis, S.; Stensballe, A.; Emmersen, J.; Pennisi, C.P.; Birkelund, S.; Zachar, V.; Fink, T. Mass spectrometry analysis of adipose-derived stem cells reveals a significant effect of hypoxia on pathways regulating extracellular matrix. Stem Cell Research \& Therapy 2016, 7, 1-14. doi:10.1186/s13287-016-0310-7.

54. Dorayappan, K.D.P.; Wanner, R.; Wallbillich, J.J.; Saini, U.; Zingarelli, R.; Suarez, A.A.; Cohn, D.E.; Selvendiran, K. Hypoxia-induced exosomes contribute to a more aggressive and chemoresistant ovarian cancer phenotype: a novel mechanism linking STAT3/Rab proteins. Oncogene 2018, 37, 3806-3821. doi:10.1038/s41388-018-0189-0.

55. Felice, F.; Piras, A.M.; Rocchiccioli, S.; Barsotti, M.C.; Santoni, T.; Pucci, A.; Burchielli, S.; Chiellini, F.; Ucciferri, N.; Solaro, R.; Altomare, A.; Cecchettini, A.; Stefano, R.D. Endothelial progenitor cell secretome delivered by novel polymeric nanoparticles in ischemic hindlimb. International Journal of Pharmaceutics 2018, 542, 82-89. doi:10.1016/j.ijpharm.2018.03.015.

56. Ontoria-Oviedo, I.; Dorronsoro, A.; Sánchez, R.; Ciria, M.; Gómez-Ferrer, M.; Buigues, M.; Grueso, E.; Tejedor, S.; García-García, F.; González-King, H.; Garcia, N.A.; Peiró-Molina, E.; Sepúlveda, P. Extracellular vesicles secreted by hypoxic AC10 cardiomyocytes modulate fibroblast cell motility. Frontiers in Cardiovascular Medicine 2018, 5, 152. doi:10.3389/fcvm.2018.00152.

57. Chandran, V.I.; Welinder, C.; Gonçalves de Oliveira, K.; Cerezo-Magaña, M.; Månsson, A.S.; Johansson, M.C.; Marko-Varga, G.; Belting, M. Global extracellular vesicle proteomic signature defines U87-MG glioma cell hypoxic status with potential implications for non-invasive diagnostics. Journal of Neuro-Oncology 2019, 144, 477-488. doi:10.1007/s11060-019-03262-4.

58. Najgebauer, H.; Jarnuczak, A.F.; Varro, A.; Sanderson, C.M. Integrative omic profiling reveals unique hypoxia induced signatures in gastric cancer associated myofibroblasts. Cancers 2019, 11, 263. doi:10.3390/cancers11020263.

59. Park, J.E.; Dutta, B.; Tse, S.W.; Gupta, N.; Tan, C.F.; Low, J.K.; Yeoh, K.W.; Kon, O.L.; Tam, J.P.; Sze, S.K. Hypoxia-induced tumor exosomes promote M2-like macrophage polarization of infiltrating myeloid cells and microRNA-mediated metabolic shift. Oncogene 2019, 38, 5158-5173. doi:10.1038/s41388-019-0782-x.

60. Dihazi, H.; Asif, A.R.; Agarwal, N.K.; Doncheva, Y.; Müller, G.A. Proteomic analysis of cellular response to osmotic stress in thick ascending limb of Henle's loop (TALH) cells. Molecular E Cellular Proteomics 2005, 4, 1445-1458. doi:10.1074/mcp.M400184-MCP200.

61. Mao, L.; Hartl, D.; Nolden, T.; Koppelstätter, A.; Klose, J.; Himmelbauer, H.; Zabel, C. Pronounced alterations of cellular metabolism and structure due to hyper- or hypo-osmosis. Journal of Proteome Research 2008, 7, 3968-3983. doi:10.1021/pr800245x.

62. Lee, M.V.; Topper, S.E.; Hubler, S.L.; Hose, J.; Wenger, C.D.; Coon, J.J.; Gasch, A.P. A dynamic model of proteome changes reveals new roles for transcript alteration in yeast. Molecular Systems Biology 2011, 7, 514. doi:10.1038/msb.2011.48.

63. Oswald, E.S.; Brown, L.M.; Bulinski, J.C.; Hung, C.T. Label-free protein profiling of adipose-derived human stem cells under hyperosmotic treatment. Journal of Proteome Research 2011, 10, 3050-3059. doi:10.1021/pr200030v. 
64. Li, J.; Ferraris, J.D.; Yu, D.; Singh, T.; Izumi, Y.; Wang, G.; Gucek, M.; Burg, M.B. Proteomic analysis of high NaCl-induced changes in abundance of nuclear proteins. Physiological Genomics 2012, 44, 1063-1071. doi:10.1152/physiolgenomics.00068.2012.

65. Chen, L.; Li, J.; Guo, T.; Ghosh, S.; Koh, S.K.; Tian, D.; Zhang, L.; Jia, D.; Beuerman, R.W.; Aebersold, R.; Chan, E.C.Y.; Zhou, L. Global metabonomic and proteomic analysis of human conjunctival epithelial cells (IOBA-NHC) in response to hyperosmotic stress. Journal of Proteome Research 2015, 14, 3982-3995. doi:10.1021/acs.jproteome.5b00443.

66. Selevsek, N.; Chang, C.Y.; Gillet, L.C.; Navarro, P.; Bernhardt, O.M.; Reiter, L.; Cheng, L.Y.; Vitek, O.; Aebersold, R. Reproducible and consistent quantification of the Saccharomyces cerevisiae proteome by SWATH-mass spectrometry. Molecular $\mathcal{E}$ Cellular Proteomics 2015, 14, 739-749. doi:10.1074/mcp.M113.035550.

67. Yang, L.B.; Dai, X.M.; Zheng, Z.Y.; Zhu, L.; Zhan, X.B.; Lin, C.C. Proteomic analysis of erythritol-producing Yarrowia lipolytica from glycerol in response to osmotic pressure. Journal of Microbiology and Biotechnology 2015, 25, 1056-1069. doi:10.4014/jmb.1412.12026.

68. Gamboni, F.; Anderson, C.; Mitra, S.; Reisz, J.A.; Nemkov, T.; Dzieciatkowska, M.; Jones, K.L.; Hansen, K.C.; D'Alessandro, A.; Banerjee, A. Hypertonic saline primes activation of the p53-p21 signaling axis in human small airway epithelial cells that prevents inflammation induced by pro-inflammatory cytokines. Journal of Proteome Research 2016, 15, 3813-3826. doi:10.1021/acs.jproteome.6b00602.

69. da Silva Rodrigues, L.N.; de Almeida Brito, W.; Parente, A.F.A.; Weber, S.S.; Bailão, A.M.; Casaletti, L.; Borges, C.L.; de Almeida Soares, C.M. Osmotic stress adaptation of Paracoccidioides lutzii, Pb01, monitored by proteomics. Fungal Genetics and Biology 2016, 95, 13-23. doi:10.1016/j.fgb.2016.08.001.

70. Jacobsen, M.D.; Beynon, R.J.; Gethings, L.A.; Claydon, A.J.; Langridge, J.I.; Vissers, J.P.C.; Brown, A.J.P.; Hammond, D.E. Specificity of the osmotic stress response in Candida albicans highlighted by quantitative proteomics. Scientific Reports 2018, 8, 14492. doi:10.1038/s41598-018-32792-6.

71. Pham, T.K.; Wright, P.C. The proteomic response of Saccharomyces cerevisiae in very high glucose conditions with amino acid supplementation. Journal of Proteome Research 2008, 7, 4766-4774. doi:10.1021/pr800331s.

72. Waanders, L.F.; Chwalek, K.; Monetti, M.; Kumar, C.; Lammert, E.; Mann, M. Quantitative proteomic analysis of single pancreatic islets. Proceedings of the National Academy of Sciences 2009, 106, 18902-18907. doi:10.1073/pnas.0908351106.

73. Wang, X.L.; Fu, A.; Spiro, C.; Lee, H.C. Proteomic analysis of vascular endothelial cells: effects of laminar shear stress and high glucose. Journal of Proteomics $\mathcal{E}$ Bioinformatics 2009, 2, 445-445. doi:10.4172/jpb.1000104.

74. Maris, M.; Ferreira, G.B.; D’Hertog, W.; Cnop, M.; Waelkens, E.; Overbergh, L.; Mathieu, C. High glucose induces dysfunction in insulin secretory cells by different pathways: a proteomic approach. Journal of Proteome Research 2010, 9, 6274-6287. doi:10.1021/pr100557w.

75. Chen, Y.H.; Chen, J.Y.; Chen, Y.W.; Lin, S.T.; Chan, H.L. High glucose-induced proteome alterations in retinal pigmented epithelium cells and its possible relevance to diabetic retinopathy. Molecular Biosystems 2012, 8, 3107-3124. doi:10.1039/C2MB25331C.

76. Schrimpe-Rutledge, A.C.; Fontès, G.; Gritsenko, M.A.; Norbeck, A.D.; Anderson, D.J.; Waters, K.M.; Adkins, J.N.; Smith, R.D.; Poitout, V.; Metz, T.O. Discovery of novel glucose-regulated proteins in isolated human pancreatic islets using LC-MS/MS-based proteomics. Journal of Proteome Research 2012, 11, 3520-3532. doi:10.1021/pr3002996.

77. Chen, J.Y.; Chou, H.C.; Chen, Y.H.; Chan, H.L. High glucose-induced proteome alterations in hepatocytes and its possible relevance to diabetic liver disease. Journal of Nutritional Biochemistry 2013, 24, 1889-1910. doi:10.1016/j.jnutbio.2013.05.006.

78. Chen, X.; Cui, Z.; Wei, S.; Hou, J.; Xie, Z.; Peng, X.; Li, J.; Cai, T.; Hang, H.; Yang, F. Chronic high glucose induced INS-1 $\beta$ cell mitochondrial dysfunction: A comparative mitochondrial proteome with SILAC. Proteomics 2013, 13, 3030-3039. doi:10.1002/pmic.201200448.

79. Liu, Z.; Dai, S.; Bones, J.; Ray, S.; Cha, S.; Karger, B.L.; Li, J.J.; Wilson, L.; Hinckle, G.; Rossomando, A. A quantitative proteomic analysis of cellular responses to high glucose media in Chinese hamster ovary cells. Biotechnology Progress 2015, 31, 1026-1038. doi:10.1002/btpr.2090. 
80. Burger, D.; Turner, M.; Xiao, F.; Munkonda, M.N.; Akbari, S.; Burns, K.D. High glucose increases the formation and pro-oxidative activity of endothelial microparticles. Diabetologia 2017, 60, 1791-1800. doi:10.1007/s00125-017-4331-2.

81. Schmudlach, A.; Felton, J.; Kennedy, R.T.; Dovichi, N.J. Bottom-up proteomics analysis of the secretome of murine islets of Langerhans in elevated glucose levels. Analyst 2017, 142, 284-291. doi:10.1039/C6AN02268E.

82. Huang, S.; Gaucher, F.; Cauty, C.; Jardin, J.; Le Loir, Y.; Jeantet, R.; Chen, X.D.; Jan, G. Growth in hyper-concentrated sweet whey triggers multi stress tolerance and spray drying survival in Lactobacillus casei BL23: from the molecular basis to new perspectives for sustainable probiotic production. Frontiers in Microbiology 2018, 9, 2548. doi:10.3389/fmicb.2018.02548.

83. Irshad, Z.; Xue, M.; Ashour, A.; Larkin, J.R.; Thornalley, P.J.; Rabbani, N. Activation of the unfolded protein response in high glucose treated endothelial cells is mediated by methylglyoxal. Scientific Reports 2019, 9, 7889. doi:10.1038/s41598-019-44358-1.

84. Meneses-Romero, E.; Hernández-Orihuela, L.; Pando-Robles, V.; López, T.D.; Oses-Prieto, J.A.; Burlingame, A.L.; Batista, C.V. Quantitative proteomic analysis reveals high interference on protein expression of H9c2 cells activated with glucose and cardiotonic steroids. Journal of Proteomics 2020, 211, 103536. doi:10.1016/j.jprot.2019.103536.

85. Madonna, R.; Pieragostino, D.; Rossi, C.; Confalone, P.; Cicalini, I.; Minnucci, I.; Zucchelli, M.; Del Boccio, P.; De Caterina, R. Simulated hyperglycemia impairs insulin signaling in endothelial cells through a hyperosmolar mechanism. Vascular Pharmacology 2020, 130, 106678. doi:10.1016/j.vph.2020.106678.

86. Pruksakorn, D.; Lirdprapamongkol, K.; Chokchaichamnankit, D.; Subhasitanont, P.; Chiablaem, K.; Svasti, J.; Srisomsap, C. Metabolic alteration of HepG2 in scaffold-based 3-D culture: Proteomic approach. Proteomics 2010, 10, 3896-3904. doi:10.1002/pmic.201000137.

87. Morrison, B.J.; Hastie, M.L.; Grewal, Y.S.; Bruce, Z.C.; Schmidt, C.; Reynolds, B.A.; Gorman, J.J.; Lopez, J.A. Proteomic comparison of MCF-7 tumoursphere and monolayer cultures. PLOS One 2012, 7, e52692. doi:10.1371/journal.pone.0052692.

88. McMahon, K.M.; Volpato, M.; Chi, H.Y.; Musiwaro, P.; Poterlowicz, K.; Peng, Y.; Scally, A.J.; Patterson, L.H.; Phillips, R.M.; Sutton, C.W. Characterization of changes in the proteome in different regions of 3D multicell tumor spheroids. Journal of Proteome Research 2012, 11, 2863-2875. doi:10.1021/pr2012472.

89. Yan, M.; Yang, X.; Wang, L.; Clark, D.; Zuo, H.; Ye, D.; Chen, W.; Zhang, P. Plasma membrane proteomics of tumor spheres identify CD166 as a novel marker for cancer stem-like cells in head and neck squamous cell carcinoma. Molecular E Cellular Proteomics 2013, 12, 3271-3284. doi:10.1074/mcp.M112.025460.

90. Zanivan, S.; Maione, F.; Hein, M.Y.; Hernández-Fernaud, J.R.; Ostasiewicz, P.; Giraudo, E.; Mann, M. SILAC-based proteomics of human primary endothelial cell morphogenesis unveils tumor angiogenic markers. Molecular E Cellular Proteomics 2013, 12, 3599-3611. doi:10.1074/mcp.M113.031344.

91. He, W.; Kuang, Y.; Xing, X.; Simpson, R.J.; Huang, H.; Yang, T.; Chen, J.; Yang, L.; Liu, E.; He, W.; Gu, J. Proteomic comparison of 3D and 2D glioma models reveals increased HLA-E expression in 3D models is associated with resistance to NK cell-mediated cytotoxicity. Journal of Proteome Research 2014, 13, 2272-2281. doi:10.1021/pr500064m.

92. Konze, S.A.; van Diepen, L.; Schröder, A.; Olmer, R.; Möller, H.; Pich, A.; Weißmann, R.; Kuss, A.W.; Zweigerdt, R.; Buettner, F.F.R. Cleavage of E-cadherin and $\beta$-catenin by calpain affects Wnt signaling and spheroid formation in suspension cultures of human pluripotent stem cells. Molecular $\mathcal{E}$ Cellular Proteomics 2014, 13, 990-1007. doi:10.1074/mcp.M113.033423.

93. Rajcevic, U.; Knol, J.; Piersma, S.; Bougnaud, S.; Fack, F.; Sundlisaeter, E.; Sondenaa, K.; Myklebust, R.; Pham, T.; Niclou, S.; Jimenez, C. Colorectal cancer derived organotypic spheroids maintain essential tissue characteristics but adapt their metabolism in culture. Proteome Science 2014, 12, 39. doi:10.1186/1477-5956-12-39.

94. Saini, R.K.R.; Attarha, S.; da Silva Santos, C.; Kolakowska, J.; Funa, K.; Souchelnytskyi, S. Proteomics of dedifferentiation of SK-N-BE2 neuroblastoma cells. Biochemical and Biophysical Research Communications 2014, 454, 202-209. doi:10.1016/j.bbrc.2014.10.065.

95. Wrzesinski, K.; Rogowska-Wrzesinska, A.; Kanlaya, R.; Borkowski, K.; Schwämmle, V.; Dai, J.; Joensen, K.E.; Wojdyla, K.; Carvalho, V.B.; Fey, S.J. The cultural divide: Exponential growth in classical 2D and metabolic equilibrium in 3D environments. PLOS One 2014, 9, e106973. doi:10.1371/journal.pone.0106973. 
96. Musrap, N.; Tuccitto, A.; Karagiannis, G.S.; Saraon, P.; Batruch, I.; Diamandis, E.P. Comparative proteomics of ovarian cancer aggregate formation reveals an increased expression of calcium-activated chloride channel regulator 1 (CLCA1). Journal of Biological Chemistry 2015, 290, 17218-17227. doi:10.1074/jbc.m115.639773.

97. Yue, X.; Lukowski, J.K.; Weaver, E.M.; Skube, S.B.; Hummon, A.B. Quantitative proteomic and phosphoproteomic comparison of 2D and 3D colon cancer cell culture models. Journal of Proteome Research 2016, 15, 4265-4276. doi:10.1021/acs.jproteome.6b00342.

98. Kim, Y.E.; Jeon, H.J.; Kim, D.; Lee, S.Y.; Kim, K.Y.; Hong, J.; Maeng, P.J.; Kim, K.R.; Kang, D. Quantitative proteomic analysis of 2D and 3D cultured colorectal cancer cells: Profiling of tankyrase inhibitor XAV939-induced proteome. Scientific Reports 2018, 8, 13255. doi:10.1038/s41598-018-31564-6.

99. Toelle, R.C.; Gaggioli, C.; Dengjel, J. Three-dimensional cell culture conditions affect the proteome of cancer-associated fibroblasts. Journal of Proteome Research 2018, 17, 2780-2789. doi:10.1021/acs.jproteome.8b00237.

100. Erhart, F.; Weiss, T.; Klingenbrunner, S.; Fischhuber, K.; Reitermaier, R.; Halfmann, A.; Blauensteiner, B.; Lötsch, D.; Spiegl-kreinecker, S.; Berger, W.; Sialana, F.J.; Lubec, G.; Felzmann, T.; Dohnal, A.; Visus, C. Spheroid glioblastoma culture conditions as antigen source for dendritic cell-based immunotherapy: spheroid proteins are survival-relevant targets but can impair immunogenic interferon $\gamma$ production. Cytotherapy 2019, 21, 643-658. doi:10.1016/j.jcyt.2019.03.002.

101. Gegotek, A.; Atalay, S.; Domingues, P.; Skrzydlewska, E. The differences in the proteome profile of cannabidiol-treated skin fibroblasts following UVA or UVB irradiation in 2D and 3D cell cultures. Cells 2019, 8, 995. doi:10.3390/cells8090995.

102. Hurrell, T.; Lilley, K.S.; Cromarty, A.D. Proteomic responses of HepG2 cell monolayers and 3D spheroids to selected hepatotoxins. Toxicology Letters 2019, 300, 40-50. doi:10.1016/j.toxlet.2018.10.030.

103. Lee, S.Y.; Park, S.B.; Kim, Y.E.; Yoo, H.M.; Hong, J.; Choi, K.J.; Kim, K.Y.; Kang, D. iTRAQ-based quantitative proteomic comparison of 2D and 3D adipocyte cell models co-cultured with macrophages using online 2D-nanoLC-ESI-MS/MS. Scientific Reports 2019, 9, 16746. doi:10.1038/s41598-019-53196-0.

104. Doron, G.; Klontzas, M.E.; Mantalaris, A.; Guldberg, R.E.; Temenoff, J.S. Multiomics characterization of mesenchymal stromal cells cultured in monolayer and as aggregates. Biotechnology and Bioengineering 2020, 117, 1761-1778. doi:10.1002/bit.27317.

105. Alldridge, L.; Metodieva, G.; Greenwood, C.; Al-Janabi, K.; Thwaites, L.; Sauven, P.; Metodiev, M. Proteome profiling of breast tumors by gel electrophoresis and nanoscale electrospray ionization mass spectrometry. Journal of Proteome Research 2008, 7, 1458-1469. doi:10.1021/pr7007829.

106. Cha, S.; Imielinski, M.B.; Rejtar, T.; Richardson, E.A.; Thakur, D.; Sgroi, D.C.; Karger, B.L. In situ proteomic analysis of human breast cancer epithelial cells using laser capture microdissection: Annotation by protein set enrichment analysis and gene ontology. Molecular E Cellular Proteomics 2010, 9, 2529-2544. doi:10.1074/mcp.M110.000398.

107. Sutton, C.W.; Rustogi, N.; Gurkan, C.; Scally, A.; Loizidou, M.A.; Hadjisavvas, A.; Kyriacou, K. Quantitative proteomic profiling of matched normal and tumor breast tissues. Journal of Proteome Research 2010, 9, 3891-3902. doi:10.1021/pr100113a.

108. Hill, J.J.; Tremblay, T.L.; Pen, A.; Li, J.; Robotham, A.C.; Lenferink, A.E.G.; Wang, E.; O'Connor-McCourt, M.; Kelly, J.F. Identification of vascular breast tumor markers by laser capture microdissection and label-free LC-MS. Journal of Proteome Research 2011, 10, 2479-2493. doi:10.1021/pr101267k.

109. Gormley, M.; Tchafa, A.; Meng, R.; Zhong, Z.; Quong, A.A. Proteomic profiling of infiltrating ductal carcinoma reveals increased cellular interactions with tissue microenvironment. Journal of Proteome Research 2012, 11, 2236-2246. doi:10.1021/pr201018y.

110. Liang, J.1.; Li, S.j.; Liu, X.g.; Li, W.f.; Hao, D.y.; Fan, Z.m. Quantitative proteomic studies on TNBC in premenopausal patients. Chemical Research in Chinese Universities 2013, 29, 500-505. doi:10.1007/s40242-013-2497-9.

111. Shaheed, S.u.; Rustogi, N.; Scally, A.; Wilson, J.; Thygesen, H.; Loizidou, M.A.; Hadjisavvas, A.; Hanby, A.; Speirs, V.; Loadman, P.; Linforth, R.; Kyriacou, K.; Sutton, C.W. Identification of stage-specific breast markers using quantitative proteomics. Journal of Proteome Research 2013, 12, 5696-5708. doi:10.1021/pr400662k. 
112. Groessl, M.; Slany, A.; Bileck, A.; Gloessmann, K.; Kreutz, D.; Jaeger, W.; Pfeiler, G.; Gerner, C. Proteome profiling of breast cancer biopsies reveals a wound healing signature of cancer-associated fibroblasts. Journal of Proteome Research 2014, 13, 4773-4782. doi:10.1021/pr500727h.

113. Panis, C.; Pizzatti, L.; Herrera, A.C.; Corrêa, S.; Binato, R.; Abdelhay, E. Label-free proteomic analysis of breast cancer molecular subtypes. Journal of Proteome Research 2014, 13, 4752-4772. doi:10.1021/pr500676x.

114. Campone, M.; Valo, I.; Jézéquel, P.; Moreau, M.; Boissard, A.; Campion, L.; Loussouarn, D.; Verriele, V.; Coqueret, O.; Guette, C. Prediction of recurrence and survival for triple-negative breast cancer (TNBC) by a protein signature in tissue samples. Molecular E Cellular Proteomics 2015, 14, 2936-2946. doi:10.1074/mcp.M115.048967.

115. Pendharkar, N.; Gajbhiye, A.; Taunk, K.; RoyChoudhury, S.; Dhali, S.; Seal, S.; Mane, A.; Abhang, S.; Santra, M.K.; Chaudhury, K.; Rapole, S. Quantitative tissue proteomic investigation of invasive ductal carcinoma of breast with luminal B HER2 positive and HER2 enriched subtypes towards potential diagnostic and therapeutic biomarkers. Journal of Proteomics 2016, 132, 112-130. doi:10.1016/j.jprot.2015.11.024.

116. Pozniak, Y.; Balint-Lahat, N.; Rudolph, J.D.; Lindskog, C.; Katzir, R.; Avivi, C.; Pontén, F.; Ruppin, E.; Barshack, I.; Geiger, T. System-wide clinical proteomics of breast cancer reveals global remodeling of tissue homeostasis. Cell Systems 2016, 2, 172-184. doi:10.1016/j.cels.2016.02.001.

117. Braakman, R.B.; Stingl, C.; Tilanus-Linthorst, M.M.; Deurzen, C.H.; Timmermans, M.A.; Smid, M.; Foekens, J.A.; Luider, T.M.; Martens, J.W.; Umar, A. Proteomic characterization of microdissected breast tissue environment provides a protein-level overview of malignant transformation. Proteomics 2017, 17, 1600213. doi:10.1002/pmic.201600213.

118. Tang, W.; Zhou, M.; Dorsey, T.H.; Prieto, D.A.; Wang, X.W.; Ruppin, E.; Veenstra, T.D.; Ambs, S. Integrated proteotranscriptomics of breast cancer reveals globally increased protein-mRNA concordance associated with subtypes and survival. Genome Medicine 2018, 10, 94. doi:10.1186/s13073-018-0602-x.

119. Gomig, T.H.B.; Cavalli, I.J.; de Souza, R.L.R.; Lucena, A.C.R.; Batista, M.; Machado, K.C.; Marchini, F.K.; Marchi, F.A.; Lima, R.S.; de Andrade Urban, C.; Cavalli, L.R.; de Souza Fonseca Ribeiro, E.M. High-throughput mass spectrometry and bioinformatics analysis of breast cancer proteomic data. Data in Brief 2019, 25, 104125. doi:10.1016/j.dib.2019.104125.

120. Liu, C.; Liu, Y.; Chen, L.; Zhang, M.; Li, W.; Cheng, H.; Zhang, B. Quantitative proteome and lysine succinylome analyses provide insights into metabolic regulation in breast cancer. Breast Cancer 2019, 26, 93-105. doi:10.1007/s12282-018-0893-1.

121. Lin, Y.; Lin, L.; Fu, F.; Wang, C.; Hu, A.; Xie, J.; Jiang, M.; Wang, Z.; Yang, L.; Zhang, J.; Chen, M.; Li, Y.; Guo, R.; Yang, P.; Shen, H. Quantitative proteomics reveals stage-specific protein regulation of triple negative breast cancer. ResearchSquare 2020, preprint. doi:10.21203/rs.2.22780/v1.

122. Watanabe, M.; Takemasa, I.; Kawaguchi, N.; Miyake, M.; Nishimura, N.; Matsubara, T.; Matsuo, E.i.; Sekimoto, M.; Nagai, K.; Matsuura, N.; Monden, M.; Nishimura, O. An application of the 2-nitrobenzenesulfenyl method to proteomic profiling of human colorectal carcinoma: A novel approach for biomarker discovery. Proteomics: Clinical Applications 2008, 2, 925-935. doi:10.1002/prca.200780111.

123. Xie, L.Q.; Zhao, C.; Cai, S.J.; Xu, Y.; Huang, L.Y.; Bian, J.S.; Shen, C.P.; Lu, H.J.; Yang, P.Y. Novel proteomic strategy reveal combined $\alpha_{1}$ antitrypsin and cathepsin $\mathrm{D}$ as biomarkers for colorectal cancer early screening. Journal of Proteome Research 2010, 9, 4701-4709. doi:10.1021/pr100406z.

124. Zhang, Y.; Ye, Y.; Shen, D.; Jiang, K.; Zhang, H.; Sun, W.; Zhang, J.; Xu, F.; Cui, Z.; Wang, S. Identification of transgelin-2 as a biomarker of colorectal cancer by laser capture microdissection and quantitative proteome analysis. Cancer Science 2010, 101, 523-529. doi:10.1111/j.1349-7006.2009.01424.x.

125. Besson, D.; Pavageau, A.H.; Valo, I.; Bourreau, A.; Bélanger, A.; Eymerit-Morin, C.; Moulière, A.; Chassevent, A.; Boisdron-Celle, M.; Morel, A.; Solassol, J.; Campone, M.; Gamelin, E.; Barré, B.; Coqueret, O.; Guette, C. A quantitative proteomic approach of the different stages of colorectal cancer establishes OLFM4 as a new nonmetastatic tumor marker. Molecular $\mathcal{E}$ Cellular Proteomics 2011, 10, M111.009712. doi:10.1074/mcp.M111.009712.

126. Jankova, L.; Chan, C.; Fung, C.L.S.; Song, X.; Kwun, S.Y.; Cowley, M.J.; Kaplan, W.; Dent, O.F.; Bokey, E.L.; Chapuis, P.H.; Baker, M.S.; Robertson, G.R.; Clarke, S.J.; Molloy, M.P. Proteomic comparison of colorectal tumours and non-neoplastic mucosa from paired patient samples using iTRAQ mass spectrometry. Molecular Biosystems 2011, 7, 2997-3005. doi:10.1039/C1MB05236E. 
127. Mikula, M.; Rubel, T.; Karczmarski, J.; Goryca, K.; Dadlez, M.; Ostrowski, J. Integrating proteomic and transcriptomic high-throughput surveys for search of new biomarkers of colon tumors. Functional and Integrative Genomics 2011, 11, 215-224. doi:10.1007/s10142-010-0200-5.

128. Shi, H.; Hood, K.A.; Hayes, M.T.; Stubbs, R.S. Proteomic analysis of advanced colorectal cancer by laser capture microdissection and two-dimensional difference gel electrophoresis. Journal of Proteomics 2011, 75, 339-351. doi:10.1016/j.jprot.2011.07.025.

129. Fan, N.J.; Gao, C.F.; Wang, C.S.; Lv, J.J.; Zhao, G.; Sheng, X.H.; Wang, X.L.; Li, D.H.; Liu, Q.Y.; Yin, J. Discovery and verification of gelsolin as a potential biomarker of colorectal adenocarcinoma in a Chinese population: Examining differential protein expression using an iTRAQ labelling-based proteomics approach. Canadian Journal of Gastroenterology 2012, 26, 41-47. doi:10.1155/2012/645218.

130. Kang, U.B.; Yeom, J.; Kim, H.J.; Kim, H.; Lee, C. Expression profiling of more than 3500 proteins of MSS-type colorectal cancer by stable isotope labeling and mass spectrometry. Journal of Proteomics 2012, 75, 3050-3062. doi:10.1016/j.jprot.2011.11.021.

131. Wiśniewski, J.R.; Ostasiewicz, P.; Duś, K.; Zielińska, D.F.; Gnad, F.; Mann, M. Extensive quantitative remodeling of the proteome between normal colon tissue and adenocarcinoma. Molecular Systems Biology 2012, 8, 611. doi:10.1038/msb.2012.44.

132. Chen, S.; Zhang, J.; Duan, L.; Zhang, Y.; Li, C.; Liu, D.; Ouyang, C.; Lu, F.; Liu, X. Identification of HnRNP M as a novel biomarker for colorectal carcinoma by quantitative proteomics. American Journal of Physiology-Gastrointestinal and Liver Physiology 2014, 306, G394-G403. doi:10.1152/ajpgi.00328.2013.

133. Sethi, M.K.; Thaysen-Andersen, M.; Kim, H.; Park, C.K.; Baker, M.S.; Packer, N.H.; Paik, Y.K.; Hancock, W.S.; Fanayan, S. Quantitative proteomic analysis of paired colorectal cancer and non-tumorigenic tissues reveals signature proteins and perturbed pathways involved in CRC progression and metastasis. Journal of Proteomics 2015, 126, 54-67. doi:10.1016/j.jprot.2015.05.037.

134. Wiśniewski, J.R.; Duś-Szachniewicz, K.; Ostasiewicz, P.; Ziółkowski, P.; Rakus, D.; Mann, M. Absolute proteome analysis of colorectal mucosa, adenoma, and cancer reveals drastic changes in fatty acid metabolism and plasma membrane transporters. Journal of Proteome Research 2015, 14, 4005-4018. doi:10.1021/acs.jproteome.5b00523.

135. Liu, X.; Xu, Y.; Meng, Q.; Zheng, Q.; Wu, J.; Wang, C.; Jia, W.; Figeys, D.; Chang, Y.; Zhou, H. Proteomic analysis of minute amount of colonic biopsies by enteroscopy sampling. Biochemical and Biophysical Research Communications 2016, 476, 286-292. doi:10.1016/j.bbrc.2016.05.114.

136. Peng, F.; Huang, Y.; Li, M.Y.; Li, G.Q.; Huang, H.C.; Guan, R.; Chen, Z.C.; Liang, S.P.; Chen, Y.H. Dissecting characteristics and dynamics of differentially expressed proteins during multistage carcinogenesis of human colorectal cancer. World Journal of Gastroenterology 2016, 22, 4515-4528. doi:10.3748/wjg.v22.i18.4515.

137. Cristobal, A.; van den Toorn, H.W.; van de Wetering, M.; Clevers, H.; Heck, A.J.; Mohammed, S. Personalized proteome profiles of healthy and tumor human colon organoids reveal both individual diversity and basic features of colorectal cancer. Cell Reports 2017, 18, 263-274. doi:10.1016/j.celrep.2016.12.016.

138. Hao, J.J.; Zhi, X.; Wang, Y.; Zhang, Z.; Hao, Z.; Ye, R.; Tang, Z.; Qian, F.; Wang, Q.; Zhu, J. Comprehensive proteomic characterization of the human colorectal carcinoma reveals signature proteins and perturbed pathways. Scientific Reports 2017, 7, 42436. doi:10.1038/srep42436.

139. Li, G.; Li, M.; Liang, X.; Xiao, Z.; Zhang, P.; Shao, M.; Peng, F.; Chen, Y.; Li, Y.; Chen, Z. Identifying DCN and HSPD1 as potential biomarkers in colon cancer using 2D-LC-MS/MS combined with iTRAQ technology. Journal of Cancer 2017, 8, 479-489. doi:10.7150/jca.17192.

140. Nishio, T.; Kurabe, N.; Goto-Inoue, N.; Nakamura, T.; Sugimura, H.; Setou, M.; Maekawa, M. Immunohistochemical expression analysis of leucine-rich PPR-motif-containing protein (LRPPRC), a candidate colorectal cancer biomarker identified by shotgun proteomics using iTRAQ. Clinica Chimica Acta 2017, 471, 276-282. doi:10.1016/j.cca.2017.06.011.

141. Quesada-Calvo, F.; Massot, C.; Bertrand, V.; Longuespée, R.; Blétard, N.; Somja, J.; Mazzucchelli, G.; Smargiasso, N.; Baiwir, D.; De Pauw-Gillet, M.C.; Delvenne, P.; Malaise, M.; Coimbra Marques, C.; Polus, M.; De Pauw, E.; Meuwis, M.A.; Louis, E. OLFM4, KNG1 and Sec24C identified by proteomics and immunohistochemistry as potential markers of early colorectal cancer stages. Clinical Proteomics 2017, 14, 9. doi:10.1186/s12014-017-9143-3. 
142. Tu, C.; Mojica, W.; Straubinger, R.M.; Li, J.; Shen, S.; Qu, M.; Nie, L.; Roberts, R.; An, B.; Qu, J. Quantitative proteomic profiling of paired cancerous and normal colon epithelial cells isolated freshly from colorectal cancer patients. Proteomics: Clinical Applications 2017, 11, 1600155. doi:10.1002/prca.201600155.

143. Zhang, Y.; Liu, Y.; Ye, Y.; Shen, D.; Zhang, H.; Huang, H.; Li, S.; Wang, S.; Ren, J. Quantitative proteome analysis of colorectal cancer-related differential proteins. Journal of Cancer Research and Clinical Oncology 2017, 143, 233-241. doi:10.1007/s00432-016-2274-5.

144. Atak, A.; Khurana, S.; Gollapalli, K.; Reddy, P.J.; Levy, R.; Ben-Salmon, S.; Hollander, D.; Donyo, M.; Heit, A.; Hotz-Wagenblatt, A.; Biran, H.; Sharan, R.; Rane, S.; Shelar, A.; Ast, G.; Srivastava, S. Quantitative mass spectrometry analysis reveals a panel of nine proteins as diagnostic markers for colon adenocarcinomas. Oncotarget 2018, 9, 13530-13544. doi:10.18632/oncotarget.24418.

145. Saleem, S.; Tariq, S.; Aleem, I.; ul Shaheed, S.; Tahseen, M.; Atiq, A.; Hassan, S.; Abu Bakar, M.; Khattak, S.; Syed, A.A.; Ahmad, A.H.; Hussain, M.; Yusuf, M.A.; Sutton, C. Proteomics analysis of colon cancer progression. Clinical Proteomics 2019, 16, 44. doi:10.1186/s12014-019-9264-y.

146. Vasaikar, S.; Huang, C.; Wang, X.; Petyuk, V.A.; Savage, S.R.; Wen, B.; Dou, Y.; Zhang, Y.; Shi, Z.; Arshad, O.A.; Gritsenko, M.A.; Zimmerman, L.J.; McDermott, J.E.; Clauss, T.R.; Moore, R.J.; Zhao, R.; Monroe, M.E.; Wang, Y.T.; Chambers, M.C.; Slebos, R.J.; Lau, K.S.; Mo, Q.; Ding, L.; Ellis, M.; Thiagarajan, M.; Kinsinger, C.R.; Rodriguez, H.; Smith, R.D.; Rodland, K.D.; Liebler, D.C.; Liu, T.; Zhang, B.; Pandey, A.; Paulovich, A.; Hoofnagle, A.; Mani, D.; Chan, D.W.; Ransohoff, D.F.; Fenyo, D.; Tabb, D.L.; Levine, D.A.; Boja, E.S.; Kuhn, E.; White, F.M.; Whiteley, G.A.; Zhu, H.; Zhang, H.; Shih, I.M.; Bavarva, J.; Whiteaker, J.; Ketchum, K.A.; Clauser, K.R.; Ruggles, K.; Elburn, K.; Hannick, L.; Watson, M.; Oberti, M.; Mesri, M.; Sanders, M.E.; Borucki, M.; Gillette, M.A.; Snyder, M.; Edwards, N.J.; Vatanian, N.; Rudnick, P.A.; McGarvey, P.B.; Mertins, P.; Townsend, R.R.; Thangudu, R.R.; Rivers, R.C.; Payne, S.H.; Davies, S.R.; Cai, S.; Stein, S.E.; Carr, S.A.; Skates, S.J.; Madhavan, S.; Hiltke, T.; Chen, X.; Zhao, Y.; Wang, Y.; Zhang, Z. Proteogenomic analysis of human colon cancer reveals new therapeutic opportunities. Cell 2019, 177, 1035-1049. doi:10.1016/j.cell.2019.03.030.

147. Wang, G.; Yang, Q.; Li, M.; Zhang, Y.; Cai, Y.; Liang, X.; Fu, Y.; Xiao, Z.; Zhou, M.; Xie, Z.; Huang, H.; Huang, Y.; Chen, Y.; He, Q.; Peng, F.; Chen, Z. Quantitative proteomic profiling of tumor-associated vascular endothelial cells in colorectal cancer. Biology Open 2019, 8, bio042838. doi:10.1242/bio.042838.

148. Li, C.; Hong, Y.; Tan, Y.X.; Zhou, H.; Ai, J.H.; Li, S.J.; Zhang, L.; Xia, Q.C.; Wu, J.R.; Wang, H.Y.; Zeng, R. Accurate qualitative and quantitative proteomic analysis of clinical hepatocellular carcinoma using laser capture microdissection coupled with isotope-coded affinity tag and two-dimensional liquid chromatography mass spectrometry. Molecular $\mathcal{E}$ Cellular Proteomics 2004, 3, $399-409$. doi:10.1074/mcp.M300133-MCP200.

149. Blanc, J.F.; Lalanne, C.; Plomion, C.; Schmitter, J.M.; Bathany, K.; Gion, J.M.; Bioulac-Sage, P.; Balabaud, C.; Bonneu, M.; Rosenbaum, J. Proteomic analysis of differentially expressed proteins in hepatocellular carcinoma developed in patients with chronic viral hepatitis C. Proteomics 2005, 5, 3778-3789. doi:10.1002/pmic.200401194.

150. Li, C.; Tan, Y.X.; Zhou, H.; Ding, S.J.; Li, S.J.; Ma, D.j.; Man, X.b.; Hong, Y.; Zhang, L.; Li, L.; Xia, Q.C.; Wu, J.R.; Wang, H.Y.; Zeng, R. Proteomic analysis of hepatitis B virus-associated hepatocellular carcinoma: Identification of potential tumor markers. Proteomics 2005, 5, 1125-1139. doi:10.1002/pmic.200401141.

151. Dos Santos, A.; Thiers, V.; Sar, S.; Derian, N.; Bensalem, N.; Yilmaz, F.; Bralet, M.P.; Ducot, B.; Bréchot, C.; Demaugre, F. Contribution of laser microdissection-based technology to proteomic analysis in hepatocellular carcinoma developing on cirrhosis. Proteomics - Clinical Applications 2007, 1, 545-554. doi:10.1002/prca.200600474.

152. Sun, W.; Xing, B.; Sun, Y.; Du, X.; Lu, M.; Hao, C.; Lu, Z.; Mi, W.; Wu, S.; Wei, H.; Gao, X.; Zhu, Y.; Jiang, Y.; Qian, X.; He, F. Proteome analysis of hepatocellular carcinoma by two-dimensional difference gel electrophoresis: Novel protein markers in hepatocellular carcinoma tissues. Molecular $\mathcal{E}$ Cellular Proteomics 2007, 6, 1798-1808. doi:10.1074/mcp.M600449-MCP200.

153. Chaerkady, R.; Harsha, H.C.; Nalli, A.; Gucek, M.; Vivekanandan, P.; Akhtar, J.; Cole, R.N.; Simmers, J.; Schulick, R.D.; Singh, S.; Torbenson, M.; Pandey, A.; Thuluvath, P.J. A quantitative proteomic approach for identification of potential biomarkers in hepatocellular carcinoma. Journal of Proteome Research 2008, 7, 4289-4298. doi:10.1021/pr800197z. 
154. Roy, L.; LaBoissière, S.; Abdou, E.; Thibault, G.; Hamel, N.; Taheri, M.; Boismenu, D.; Lanoix, J.; Kearney, R.E.; Paiement, J. Proteomic analysis of the transitional endoplasmic reticulum in hepatocellular carcinoma: An organelle perspective on cancer. Biochimica et Biophysica Acta (BBA) - Proteins and Proteomics 2010, 1804, 1869-1881. doi:10.1016/j.bbapap.2010.05.008.

155. Lee, Y.Y.; McKinney, K.Q.; Ghosh, S.; Iannitti, D.A.; Martinie, J.B.; Caballes, F.R.; Russo, M.W.; Ahrens, W.A.; Lundgren, D.H.; Han, D.K.; Bonkovsky, H.L.; Hwang, S.I. Subcellular tissue proteomics of hepatocellular carcinoma for molecular signature discovery. Journal of Proteome Research 2011, 10, 5070-5083. doi:10.1021/pr2005204.

156. Li, C.; Ruan, H.Q.; Liu, Y.S.; Xu, M.J.; Dai, J.; Sheng, Q.H.; Tan, Y.X.; Yao, Z.Z.; Wang, H.Y.; Wu, J.R.; Zeng, R. Quantitative proteomics reveal up-regulated protein expression of the SET complex associated with hepatocellular carcinoma. Journal of Proteome Research 2012, 11, 871-885. doi:10.1021/pr2006999.

157. Kimura, K.; Ojima, H.; Kubota, D.; Sakumoto, M.; Nakamura, Y.; Tomonaga, T.; Kosuge, T.; Kondo, T. Proteomic identification of the macrophage-capping protein as a protein contributing to the malignant features of hepatocellular carcinoma. Journal of Proteomics 2013, 78, 362-373. doi:10.1016/j.jprot.2012.10.004.

158. Megger, D.A.; Bracht, T.; Kohl, M.; Ahrens, M.; Naboulsi, W.; Weber, F.; Hoffmann, A.C.; Stephan, C.; Kuhlmann, K.; Eisenacher, M.; Schlaak, J.F.; Baba, H.A.; Meyer, H.E.; Sitek, B. Proteomic differences between hepatocellular carcinoma and nontumorous liver tissue investigated by a combined gel-based and label-free quantitative proteomics study. Molecular $\mathcal{E}$ Cellular Proteomics 2013, 12, 2006-2020. doi:10.1074/mcp.M113.028027.

159. Xu, B.; Wang, F.; Song, C.; Sun, Z.; Cheng, K.; Tan, Y.; Wang, H.; Zou, H. Large-scale proteome quantification of hepatocellular carcinoma tissues by a three-dimensional liquid chromatography strategy integrated with sample preparation. Journal of Proteome Research 2014, 13, 3645-3654. doi:10.1021/pr500200s.

160. Borlak, J.; Singh, P.; Gazzana, G. Proteome mapping of epidermal growth factor induced hepatocellular carcinomas identifies novel cell metabolism targets and mitogen activated protein kinase signalling events. BMC Genomics 2015, 16, 124. doi:10.1186/s12864-015-1312-z.

161. Reis, H.; Pütter, C.; Megger, D.A.; Bracht, T.; Weber, F.; Hoffmann, A.C.; Bertram, S.; Wohlschläger, J.; Hagemann, S.; Eisenacher, M.; Scherag, A.; Schlaak, J.F.; Canbay, A.; Meyer, H.E.; Sitek, B.; Baba, H.A. A structured proteomic approach identifies 14-3-3Sigma as a novel and reliable protein biomarker in panel based differential diagnostics of liver tumors. Biochimica et Biophysica Acta (BBA) - Proteins and Proteomics 2015, 1854, 641-650. doi:10.1016/j.bbapap.2014.10.024.

162. Naboulsi, W.; Bracht, T.; Megger, D.A.; Reis, H.; Ahrens, M.; Turewicz, M.; Eisenacher, M.; Tautges, S.; Canbay, A.E.; Meyer, H.E.; Weber, F.; Baba, H.A.; Sitek, B. Quantitative proteome analysis reveals the correlation between endocytosis-associated proteins and hepatocellular carcinoma dedifferentiation. Biochimica et Biophysica Acta (BBA) - Proteins and Proteomics 2016, 1864, 1579-1585. doi:10.1016/j.bbapap.2016.08.005.

163. Naboulsi, W.; Megger, D.A.; Bracht, T.; Kohl, M.; Turewicz, M.; Eisenacher, M.; Voss, D.M.; Schlaak, J.F.; Hoffmann, A.C.; Weber, F.; Baba, H.A.; Meyer, H.E.; Sitek, B. Quantitative tissue proteomics analysis reveals versican as potential biomarker for early-stage hepatocellular carcinoma. Journal of Proteome Research 2016, 15, 38-47. doi:10.1021/acs.jproteome.5b00420.

164. Qi, Y.; Xu, F.; Chen, L.; Li, Y.; Xu, Z.; Zhang, Y.; Wei, W.; Su, N.; Zhang, T.; Fan, F.; Wang, X.; Qin, X.; Zhang, L.; Liu, Y.; Xu, P. Quantitative proteomics reveals FLNC as a potential progression marker for the development of hepatocellular carcinoma. Oncotarget 2016, 7, 68242-68252. doi:10.18632/oncotarget.11921.

165. Guo, J.; Jing, R.; Zhong, J.H.; Dong, X.; Li, Y.X.; Liu, Y.K.; Huang, T.R.; Zhang, C.Y. Identification of CD14 as a potential biomarker of hepatocellular carcinoma using iTRAQ quantitative proteomics. Oncotarget 2017, 8, 62011-62028. doi:10.18632/oncotarget.18782.

166. Gao, Y.; Wang, X.; Sang, Z.; Li, Z.; Liu, F.; Mao, J.; Yan, D.; Zhao, Y.; Wang, H.; Li, P.; Ying, X.; Zhang, X.; He, K.; Wang, H. Quantitative proteomics by SWATH-MS reveals sophisticated metabolic reprogramming in hepatocellular carcinoma tissues. Scientific Reports 2017, 7, 45913. doi:10.1038/srep45913.

167. Qiao, Z.; Pan, X.; Parlayan, C.; Ojima, H.; Kondo, T. Proteomic study of hepatocellular carcinoma using a novel modified aptamer-based array (SOMAscan ${ }^{\mathrm{TM}}$ ) platform. Biochimica et Biophysica Acta (BBA) - Proteins and Proteomics 2017, 1865, 434-443. doi:10.1016/j.bbapap.2016.09.011. 
168. Wang, Y.; Liu, H.; Liang, D.; Huang, Y.; Zeng, Y.; Xing, X.; Xia, J.; Lin, M.; Han, X.; Liao, N.; Liu, X.; Liu, J. Reveal the molecular signatures of hepatocellular carcinoma with different sizes by iTRAQ based quantitative proteomics. Journal of Proteomics 2017, 150, 230-241. doi:10.1016/j.jprot.2016.09.008.

169. Buczak, K.; Ori, A.; Kirkpatrick, J.M.; Holzer, K.; Dauch, D.; Roessler, S.; Endris, V.; Lasitschka, F.; Parca, L.; Schmidt, A.; Zender, L.; Schirmacher, P.; Krijgsveld, J.; Singer, S.; Beck, M. Spatial tissue proteomics quantifies inter- and intratumor heterogeneity in hepatocellular carcinoma (HCC). Molecular $\mathcal{E}$ Cellular Proteomics 2018, 17, 810-825. doi:10.1074/mcp.RA117.000189.

170. Yang, J.; Xie, Q.; Zhou, H.; Chang, L.; Wei, W.; Wang, Y.; Li, H.; Deng, Z.; Xiao, Y.; Wu, J.; Xu, P.; Hong, X. Proteomic analysis and NIR-II imaging of MCM2 protein in hepatocellular carcinoma. Journal of Proteome Research 2018, 17, 2428-2439. doi:10.1021/acs.jproteome.8b00181.

171. Berndt, N.; Egners, A.; Mastrobuoni, G.; Vvedenskaya, O.; Fragoulis, A.; Dugourd, A.; Bulik, S.; Pietzke, M.; Bielow, C.; van Gassel, R.; Damink, S.W.O.; Erdem, M.; Saez-Rodriguez, J.; Holzhütter, H.G.; Kempa, S.; Cramer, T. Kinetic modelling of quantitative proteome data predicts metabolic reprogramming of liver cancer. British Journal of Cancer 2020, 122, 233-244. doi:10.1038/s41416-019-0659-3.

172. Gao, Q.; Zhu, H.; Dong, L.; Shi, W.; Chen, R.; Song, Z.; Huang, C.; Li, J.; Dong, X.; Zhou, Y.; Liu, Q.; Ma, L.; Wang, X.; Zhou, J.; Liu, Y.; Boja, E.; Robles, A.I.; Ma, W.; Wang, P.; Li, Y.; Ding, L.; Wen, B.; Zhang, B.; Rodriguez, H.; Gao, D.; Zhou, H.; Fan, J. Integrated proteogenomic characterization of HBV-related hepatocellular carcinoma. Cell 2019, 179, 561-577. doi:10.1016/j.cell.2019.08.052.

173. Jiang, Y.; Sun, A.; Zhao, Y.; Ying, W.; Sun, H.; Yang, X.; Xing, B.; Sun, W.; Ren, L.; Hu, B.; Li, C.; Zhang, L.; Qin, G.; Zhang, M.; Chen, N.; Zhang, M.; Huang, Y.; Zhou, J.; Zhao, Y.; Liu, M.; Zhu, X.; Qiu, Y.; Sun, Y.; Huang, C.; Yan, M.; Wang, M.; Liu, W.; Tian, F.; Xu, H.; Zhou, J.; Wu, Z.; Shi, T.; Zhu, W.; Qin, J.; Xie, L.; Fan, J.; Qian, X.; He, F.; He, F.; Qian, X.; Qin, J.; Jiang, Y.; Ying, W.; Sun, W.; Zhu, Y.; Zhu, W.; Wang, Y.; Yang, D.; Liu, W.; Liu, Q.; Yang, X.; Zhen, B.; Wu, Z.; Fan, J.; Sun, H.; Qian, J.; Hong, T.; Shen, L.; Xing, B.; Yang, P.; Shen, H.; Zhang, L.; Cheng, S.; Cai, J.; Zhao, X.; Sun, Y.; Xiao, T.; Mao, Y.; Chen, X.; Wu, D.; Chen, L.; Dong, J.; Deng, H.; Tan, M.; Wu, Z.; Zhao, Q.; Shen, Z.; Chen, X.; Gao, Y.; Sun, W.; Wang, T.; Liu, S.; Lin, L.; Zi, J.; Lou, X.; Zeng, R.; Wu, Y.; Cai, S.; Jiang, B.; Chen, A.; Li, Z.; Yang, F.; Chen, X.; Sun, Y.; Wang, Q.; Zhang, Y.; Wang, G.; Chen, Z.; Qin, W.; Li, Z.; Chinese Human Proteome Project Consortium (CNHPP). Proteomics identifies new therapeutic targets of early-stage hepatocellular carcinoma. Nature 2019, 567, 257-261. doi:10.1038/s41586-019-0987-8.

174. Zhu, Y.; Zhu, J.; Lu, C.; Zhang, Q.; Xie, W.; Sun, P.; Dong, X.; Yue, L.; Sun, Y.; Yi, X.; Zhu, T.; Ruan, G.; Aebersold, R.; Huang, S.; Guo, T. Identification of protein abundance changes in hepatocellular carcinoma tissues using PCT-SWATH. Proteomics: Clinical Applications 2019, 13, 1700179. doi:10.1002/prca.201700179.

175. Gao, H.; Zhang, F.; Liang, S.; Zhang, Q.; Lyu, M.; Qian, L.; Liu, W.; Ge, W.; Chen, C.; Yi, X.; Zhu, J.; Lu, C.; Sun, P.; Liu, K.; Zhu, Y.; Guo, T. Accelerated lysis and proteolytic digestion of biopsy-level fresh-frozen and FFPE tissue samples using pressure cycling technology. Journal of Proteome Research 2020, 19, 1982-1990. doi:10.1021/acs.jproteome.9b00790.

176. Shin, H.; Cha, H.J.; Lee, M.J.; Na, K.; Park, D.; Kim, C.Y.; Han, D.H.; Kim, H.; Paik, Y.K. Identification of ALDH6A1 as a potential molecular signature in hepatocellular carcinoma via quantitative profiling of the mitochondrial proteome. Journal of Proteome Research 2020, 19, 1684-1695. doi:10.1021/acs.jproteome.9b00846.

177. Li, C.; Xiao, Z.; Chen, Z.; Zhang, X.; Li, J.; Wu, X.; Li, X.; Yi, H.; Li, M.; Zhu, G.; Liang, S. Proteome analysis of human lung squamous carcinoma. Proteomics 2006, 6, 547-558. doi:10.1002/pmic.200500256.

178. Kikuchi, T.; Hassanein, M.; Amann, J.M.; Liu, Q.; Slebos, R.J.C.; Rahman, S.M.J.; Kaufman, J.M.; Zhang, X.; Hoeksema, M.D.; Harris, B.K.; Li, M.; Shyr, Y.; Gonzalez, A.L.; Zimmerman, L.J.; Liebler, D.C.; Massion, P.P.; Carbone, D.P. In-depth proteomic analysis of nonsmall cell lung cancer to discover molecular targets and candidate biomarkers. Molecular E Cellular Proteomics 2012, 11, 916-932. doi:10.1074/mcp.M111.015370.

179. Yan, X.; Lan-Qin, C.; Long-Yu, J.; Zhu-Chu, C.; Gu-Qing, Z.; Can-E, T.; Guo-Qing, L.; Chao-Jun, D.; Fang, P.; Zhi-Qiang, X.; Cui, L. Quantitative proteomic study of human lung squamous carcinoma and normal bronchial epithelial acquired by laser capture microdissection. Journal of Biomedicine and Biotechnology 2012, 2012, 510418. doi:10.1155/2012/510418.

180. Zeng, G.Q.; Zhang, P.F.; Deng, X.; Yu, F.L.; Li, C.; Xu, Y.; Yi, H.; Li, M.Y.; Hu, R.; Zuo, J.H.; Li, X.H.; Wan, X.X.; Qu, J.Q.; He, Q.Y.; Li, J.H.; Ye, X.; Chen, Y.; Li, J.Y.; Xiao, Z.Q. Identification of candidate biomarkers 
for early detection of human lung squamous cell cancer by quantitative proteomics. Molecular $\mathcal{E}$ Cellular Proteomics 2012, 11, M111.013946. doi:10.1074/mcp.M111.013946.

181. Zhang, P.F.; Zeng, G.Q.; Yi, L.Z.; Liu, J.P.; Wan, X.X.; Qu, J.Q.; Li, J.H.; Li, C.; Tang, C.E.; Hu, R.; Ye, X.; Chen, Y.; Chen, Z.C.; Xiao, Z.Q. Identification of integrin $\beta 1$ as a prognostic biomarker for human lung adenocarcinoma using 2D-LC-MS/MS combined with iTRAQ technology. Oncology Reports 2013, 30, 341-349. doi:10.3892/or.2013.2477.

182. Lihong, H.; Linlin, G.; Yiping, G.; Yang, S.; Xiaoyu, Q.; Zhuzhu, G.; Xiaohan, Y.; Xin, Z.; Liyan, X.; Shujuan, S. Proteomics approaches for identification of tumor relevant protein targets in pulmonary squamous cell carcinoma by 2D-DIGE-MS. PLOS One 2014, 9, e95121. doi:10.1371/journal.pone.0095121.

183. Li, L.; Wei, Y.; To, C.; Zhu, C.Q.; Tong, J.; Pham, N.A.; Taylor, P.; Ignatchenko, V.; Ignatchenko, A.; Zhang, W.; Wang, D.; Yanagawa, N.; Li, M.; Pintilie, M.; Liu, G.; Muthuswamy, L.; Shepherd, F.A.; Tsao, M.S.; Kislinger, T.; Moran, M.F. Integrated Omic analysis of lung cancer reveals metabolism proteome signatures with prognostic impact. Nature Communications 2014, 5, 5469. doi:10.1038/ncomms6469.

184. Zhang, X.; Li, W.; Hou, Y.; Niu, Z.; Zhong, Y.; Zhang, Y.; Yang, S. Comparative membrane proteomic analysis between lung adenocarcinoma and normal tissue by iTRAQ labeling mass spectrometry. American Journal of Translational Research 2014, 6, 267-280.

185. Zhuo, H.; Lyu, Z.; Su, J.; He, J.; Pei, Y.; Cheng, X.; Zhou, N.; Lu, X.; Zhou, S.; Zhao, Y. Effect of lung squamous cell carcinoma tumor microenvironment on the CD105+ endothelial cell proteome. Journal of Proteome Research 2014, 13, 4717-4729. doi:10.1021/pr5006229.

186. Kato, Y.; Nakamura, H.; Tojo, H.; Nomura, M.; Nagao, T.; Kawamura, T.; Kodama, T.; Ohira, T.; Ikeda, N.; Fehniger, T.; Marko-Varga, G.; Nishimura, T.; Kato, H. A proteomic profiling of laser-microdissected lung adenocarcinoma cells of early lepidic-types. Clinical and Translational Medicine 2015, 4, 24. doi:10.1186/s40169-015-0064-3.

187. Backes, C.; Ludwig, N.; Leidinger, P.; Huwer, H.; Tenzer, S.; Fehlmann, T.; Franke, A.; Meese, E.; Lenhof, H.P.; Keller, A. Paired proteomics, transcriptomics and miRNomics in non-small cell lung cancers: Known and novel signaling cascades. Oncotarget 2016, 7, 71514-71525. doi:10.18632/oncotarget.11723.

188. Fahrmann, J.F.; Grapov, D.; Phinney, B.S.; Stroble, C.; DeFelice, B.C.; Rom, W.; Gandara, D.R.; Zhang, Y.; Fiehn, O.; Pass, H.; Miyamoto, S. Proteomic profiling of lung adenocarcinoma indicates heightened DNA repair, antioxidant mechanisms and identifies LASP1 as a potential negative predictor of survival. Clinical Proteomics 2016, 13, 31. doi:10.1186/s12014-016-9132-y.

189. Jin, H.; Cheng, X.; Pei, Y.; Fu, J.; Lyu, Z.; Peng, H.; Yao, Q.; Jiang, Y.; Luo, L.; Zhuo, H. Identification and verification of transgelin-2 as a potential biomarker of tumor-derived lung-cancer endothelial cells by comparative proteomics. Journal of Proteomics 2016, 136, 77-88. doi:10.1016/j.jprot.2015.12.012.

190. Hsu, C.H.; Hsu, C.W.; Hsueh, C.; Wang, C.L.; Wu, Y.C.; Wu, C.C.; Liu, C.C.; Yu, J.S.; Chang, Y.S.; Yu, C.J. Identification and characterization of potential biomarkers by quantitative tissue proteomics of primary lung adenocarcinoma. Molecular E Cellular Proteomics 2016, 15, 2396-2410. doi:10.1074/mcp.M115.057026.

191. Tenzer, S.; Leidinger, P.; Backes, C.; Huwer, H.; Hildebrandt, A.; Lenhof, H.P.; Wesse, T.; Franke, A.; Meese, E.; Keller, A. Integrated quantitative proteomic and transcriptomic analysis of lung tumor and control tissue: A lung cancer showcase. Oncotarget 2016, 7, 14857-14870. doi:10.18632/oncotarget.7562.

192. Fahrmann, J.F.; Grapov, D.; Wanichthanarak, K.; DeFelice, B.C.; Salemi, M.R.; Rom, W.N.; Gandara, D.R.; Phinney, B.S.; Fiehn, O.; Pass, H.; Miyamoto, S. Integrated metabolomics and proteomics highlight altered nicotinamide and polyamine pathways in lung adenocarcinoma. Carcinogenesis 2017, 38, 271-280. doi:10.1093/carcin/bgw205.

193. Li, W.; Zhang, X.; Wang, W.; Sun, R.; Liu, B.; Ma, Y.; Zhang, W.; Ma, L.; Jin, Y.; Yang, S. Quantitative proteomics analysis of mitochondrial proteins in lung adenocarcinomas and normal lung tissue using iTRAQ and tandem mass spectrometry. American Journal of Translational Research 2017, 9, 3918-3934.

194. Stewart, P.A.; Fang, B.; Slebos, R.J.C.; Zhang, G.; Borne, A.L.; Fellows, K.; Teer, J.K.; Chen, Y.A.; Welsh, E.; Eschrich, S.A.; Haura, E.B.; Koomen, J.M. Relative protein quantification and accessible biology in lung tumor proteomes from four LC-MS/MS discovery platforms. Proteomics 2017, 17, 1600300. doi:10.1002/pmic.201600300.

195. Wang, K.; Li, H.; Chen, R.; Zhang, Y.; Sun, X.X.; Huang, W.; Bian, H.; Chen, Z.N. Combination of CALR and PDIA3 is a potential prognostic biomarker for non-small cell lung cancer. Oncotarget 2017, 8, 96945-96957. doi:10.18632/oncotarget.18547. 
196. Yang, S.; Chen, L.; Chan, D.W.; Li, Q.K.; Zhang, H. Protein signatures of molecular pathways in non-small cell lung carcinoma (NSCLC): comparison of glycoproteomics and global proteomics. Clinical Proteomics 2017, 14, 31. doi:10.1186/s12014-017-9166-9.

197. Lu, Z.; Hu, L.; Evers, S.; Chen, J.; Shen, Y. Differential expression profiling of human pancreatic adenocarcinoma and healthy pancreatic tissue. Proteomics 2004, 4, 3975-3988. doi:10.1002/pmic.200300863.

198. Chen, R.; Yi, E.C.; Donohoe, S.; Pan, S.; Eng, J.; Cooke, K.; Crispin, D.A.; Lane, Z.; Goodlett, D.R.; Bronner, M.P.; Aebersold, R.; Brentnall, T.A. Pancreatic cancer proteome: The proteins that underlie invasion, metastasis, and immunologic escape. Gastroenterology 2005, 129, 1187-1197. doi:10.1053/j.gastro.2005.08.001.

199. Crnogorac-Jurcevic, T.; Gangeswaran, R.; Bhakta, V.; Capurso, G.; Lattimore, S.; Akada, M.; Sunamura, M.; Prime, W.; Campbell, F.; Brentnall, T.A.; Costello, E.; Neoptolemos, J.; Lemoine, N.R. Proteomic analysis of chronic pancreatitis and pancreatic adenocarcinoma. Gastroenterology 2005, 129, 1454-1463. doi:10.1053/j.gastro.2005.08.012.

200. Cui, Y.; Tian, M.; Zong, M.; Teng, M.; Chen, Y.; Lu, J.; Jiang, J.; Liu, X.; Han, J. Proteomic analysis of pancreatic ductal adenocarcinoma compared with normal adjacent pancreatic tissue and pancreatic benign cystadenoma. Pancreatology 2009, 9, 89-98. doi:10.1159/000178879.

201. McKinney, K.Q.; Lee, Y.Y.; Choi, H.S.; Groseclose, G.; Iannitti, D.A.; Martinie, J.B.; Russo, M.W.; Lundgren, D.H.; Han, D.K.; Bonkovsky, H.L.; Hwang, S.I. Discovery of putative pancreatic cancer biomarkers using subcellular proteomics. Journal of Proteomics 2011, 74, 79-88. doi:10.1016/j.jprot.2010.08.006.

202. Pan, S.; Chen, R.; Stevens, T.; Bronner, M.P.; May, D.; Tamura, Y.; McIntosh, M.W.; Brentnall, T.A. Proteomics portrait of archival lesions of chronic pancreatitis. PLOS One 2011, 6, e27574. doi:10.1371/journal.pone.0027574.

203. Turtoi, A.; Musmeci, D.; Wang, Y.; Dumont, B.; Somja, J.; Bevilacqua, G.; De Pauw, E.; Delvenne, P.; Castronovo, V. Identification of novel accessible proteins bearing diagnostic and therapeutic potential in human pancreatic ductal adenocarcinoma. Journal of Proteome Research 2011, 10, 4302-4313. doi:10.1021/pr200527z.

204. Kojima, K.; Bowersock, G.J.; Kojima, C.; Klug, C.A.; Grizzle, W.E.; Mobley, J.A. Validation of a robust proteomic analysis carried out on formalin-fixed paraffin-embedded tissues of the pancreas obtained from mouse and human. Proteomics 2012, 12, 3393-3402. doi:10.1002/pmic.201100663.

205. Kawahara, T.; Hotta, N.; Ozawa, Y.; Kato, S.; Kano, K.; Yokoyama, Y.; Nagino, M.; Takahashi, T.; Yanagisawa, K. Quantitative proteomic profiling identifies DPYSL3 as pancreatic ductal adenocarcinoma-associated molecule that regulates cell adhesion and migration by stabilization of focal adhesion complex. PLOS One 2013, 8, e79654. doi:10.1371/journal.pone.0079654.

206. Kosanam, H.; Prassas, I.; Chrystoja, C.C.; Soleas, I.; Chan, A.; Dimitromanolakis, A.; Blasutig, I.M.; Rückert, F.; Gruetzmann, R.; Pilarsky, C.; Maekawa, M.; Brand, R.; Diamandis, E.P. Laminin, gamma 2 (LAMC2): A promising new putative pancreatic cancer biomarker identified by proteomic analysis of pancreatic adenocarcinoma tissues. Molecular E Cellular Proteomics 2013, 12, 2820-2832. doi:10.1074/mcp.M112.023507.

207. Wang, W.S.; Liu, X.H.; Liu, L.X.; Jin, D.Y.; Yang, P.Y.; Wang, X.L. Identification of proteins implicated in the development of pancreatic cancer-associated diabetes mellitus by iTRAQ-based quantitative proteomics. Journal of Proteomics 2013, 84, 52-60. doi:10.1016/j.jprot.2013.03.031.

208. Yu, J.; Kim, K.; Kang, M.; Kim, H.; Kim, S.W.; Jang, J.Y.; Kim, Y. Development of candidate biomarkers for pancreatic ductal adenocarcinoma using multiple reaction monitoring. Biotechnology and Bioprocess Engineering 2013, 18, 1038-1047. doi:10.1007/s12257-013-0421-2.

209. Zhu, J.; Nie, S.; Wu, J.; Lubman, D.M. Target proteomic profiling of frozen pancreatic CD24+ adenocarcinoma tissues by immuno-laser capture microdissection and nano-LC-MS/MS. Journal of Proteome Research 2013, 12, 2791-2804. doi:10.1021/pr400139c.

210. Iuga, C.; Seicean, A.; Iancu, C.; Buiga, R.; Sappa, P.K.; Völker, U.; Hammer, E. Proteomic identification of potential prognostic biomarkers in resectable pancreatic ductal adenocarcinoma. Proteomics 2014, 14, 945-955. doi:10.1002/pmic.201300402.

211. Britton, D.; Zen, Y.; Quaglia, A.; Selzer, S.; Mitra, V.; Lößner, C.; Jung, S.; Böhm, G.; Schmid, P.; Prefot, P.; Hoehle, C.; Koncarevic, S.; Gee, J.; Nicholson, R.; Ward, M.; Castellano, L.; Stebbing, J.; Zucht, H.D.; Sarker, D.; Heaton, N.; Pike, I. Quantification of pancreatic cancer proteome and phosphorylome: Indicates 
molecular events likely contributing to cancer and activity of drug targets. PLOS One 2014, 9, e90948. doi:10.1371/journal.pone.0090948.

212. Mirus, J.E.; Zhang, Y.; Hollingsworth, M.A.; Solan, J.L.; Lampe, P.D.; Hingorani, S.R. Spatiotemporal proteomic analyses during pancreas cancer progression identifies serine/threonine stress kinase 4 (STK4) as a novel candidate biomarker for early stage disease. Molecular \& Cellular Proteomics 2014, 13, 3484-3496. doi:10.1074/mcp.M113.036517.

213. Boj, S.; Hwang, C.I.; Baker, L.; Chio, I.; Engle, D.; Corbo, V.; Jager, M.; Ponz-Sarvise, M.; Tiriac, H.; Spector, M.; Gracanin, A.; Oni, T.; Yu, K.; van Boxtel, R.; Huch, M.; Rivera, K.; Wilson, J.; Feigin, M.; Öhlund, D.; Handly-Santana, A.; Ardito-Abraham, C.; Ludwig, M.; Elyada, E.; Alagesan, B.; Biffi, G.; Yordanov, G.; Delcuze, B.; Creighton, B.; Wright, K.; Park, Y.; Morsink, F.; Molenaar, I.; Borel Rinkes, I.; Cuppen, E.; Hao, Y.; Jin, Y.; Nijman, I.; Iacobuzio-Donahue, C.; Leach, S.; Pappin, D.; Hammell, M.; Klimstra, D.; Basturk, O.; Hruban, R.; Offerhaus, G.; Vries, R.; Clevers, H.; Tuveson, D. Organoid models of human and mouse ductal pancreatic cancer. Cell 2015, 160, 324-338. doi:10.1016/j.cell.2014.12.021.

214. Kuo, K.K.; Kuo, C.J.; Chiu, C.Y.; Liang, S.S.; Huang, C.H.; Chi, S.W.; Tsai, K.B.; Chen, C.Y.; Hsi, E.; Cheng, K.H.; Chiou, S.H. Quantitative proteomic analysis of differentially expressed protein profiles involved in pancreatic ductal adenocarcinoma. Pancreas 2016, 45, 71-83. doi:10.1097/MPA.0000000000000388.

215. Coleman, O.; Henry, M.; O’Neill, F.; Roche, S.; Swan, N.; Boyle, L.; Murphy, J.; Meiller, J.; Conlon, N.T.; Geoghegan, J.; Conlon, K.C.; Lynch, V.; Straubinger, N.L.; Straubinger, R.M.; McVey, G.; Moriarty, M.; Meleady, P.; Clynes, M. A comparative quantitative LC-MS/MS profiling analysis of human pancreatic adenocarcinoma, adjacent-normal tissue, and patient-derived tumour xenografts. Proteomes 2018, 6, 45. doi:10.3390/proteomes6040045.

216. Song, Y.; Wang, Q.; Wang, D.; Li, J.; Yang, J.; Li, H.; Wang, X.; Jin, X.; Jing, R.; Yang, J.H.; Su, H. Label-free quantitative proteomics unravels carboxypeptidases as the novel biomarker in pancreatic ductal adenocarcinoma. Translational Oncology 2018, 11, 691-699. doi:10.1016/j.tranon.2018.03.005.

217. Zhou, Q.; Andersson, R.; Hu, D.; Bauden, M.; Kristl, T.; Sasor, A.; Pawłowski, K.; Pla, I.; Hilmersson, K.S.; Zhou, M.; Lu, F.; Marko-Varga, G.; Ansari, D. Quantitative proteomics identifies brain acid soluble protein 1 (BASP1) as a prognostic biomarker candidate in pancreatic cancer tissue. EBioMedicine 2019, 43, 282-294. doi:10.1016/j.ebiom.2019.04.008.

218. Garbis, S.D.; Tyritzis, S.I.; Roumeliotis, T.; Zerefos, P.; Giannopoulou, E.G.; Vlahou, A.; Kossida, S.; Diaz, J.; Vourekas, S.; Tamvakopoulos, C.; Pavlakis, K.; Sanoudou, D.; Constantinides, C.A. Search for potential markers for prostate cancer diagnosis, prognosis and treatment in clinical tissue specimens using amine-specific isobaric tagging (iTRAQ) with two-dimensional liquid chromatography and tandem mass spectrometry. Journal of Proteome Research 2008, 7, 3146-3158. doi:10.1021/pr800060r.

219. Khan, A.P.; Poisson, L.M.; Bhat, V.B.; Fermin, D.; Zhao, R.; Kalyana-Sundaram, S.; Michailidis, G.; Nesvizhskii, A.I.; Omenn, G.S.; Chinnaiyan, A.M.; Sreekumar, A. Quantitative proteomic profiling of prostate cancer reveals a role for miR-128 in prostate cancer. Molecular E Cellular Proteomics 2010, 9, $298-312$. doi:10.1074/mcp.M900159-MCP200.

220. Han, Z.d.; Zhang, Y.q.; He, H.c.; Dai, Q.s.; Qin, G.q.; Chen, J.h.; Cai, C.; Fu, X.; Bi, X.c.; Zhu, J.g.; Liao, D.j.; Lu, X.p.; Mo, Z.y.; Zhu, Y.p.; Zhong, W.d. Identification of novel serological tumor markers for human prostate cancer using integrative transcriptome and proteome analysis. Medical Oncology 2012, 29, 2877-2888. doi:10.1007/s12032-011-0149-9.

221. Jiang, F.n.; He, H.c.; Zhang, Y.q.; Yang, D.l.; Huang, J.h.; Zhu, Y.x.; Mo, R.j.; Chen, G.; Yang, S.b.; Chen, Y.r.; Zhong, W.d.; Zhou, W.l. An integrative proteomics and interaction network-based classifier for prostate cancer diagnosis. PLOS One 2013, 8, e63941. doi:10.1371/journal.pone.0063941.

222. Liu, Y.; Chen, J.; Sethi, A.; Li, Q.K.; Chen, L.; Collins, B.; Gillet, L.C.J.; Wollscheid, B.; Zhang, H.; Aebersold, R. Glycoproteomic analysis of prostate cancer tissues by SWATH mass spectrometry discovers $\mathrm{N}$-acylethanolamine acid amidase and protein tyrosine kinase 7 as signatures for tumor aggressiveness. Molecular \& Cellular Proteomics 2014, 13, 1753-1768. doi:10.1074/mcp.M114.038273.

223. Chen, C.; Zhang, L.G.; Liu, J.; Han, H.; Chen, N.; Yao, A.L.; Kang, S.S.; Gao, W.X.; Shen, H.; Zhang, L.J.; Li, Y.P.; Cao, F.H.; Li, Z.G. Bioinformatics analysis of differentially expressed proteins in prostate cancer based on proteomics data. OncoTargets and Therapy 2016, 9, 1545-1557. doi:10.2147/OTT.S98807.

224. Iglesias-Gato, D.; Wikström, P.; Tyanova, S.; Lavallee, C.; Thysell, E.; Carlsson, J.; Hägglöf, C.; Cox, J.; Andrén, O.; Stattin, P.; Egevad, L.; Widmark, A.; Bjartell, A.; Collins, C.C.; Bergh, A.; Geiger, T.; Mann, 
M.; Flores-Morales, A. The proteome of primary prostate cancer. European Urology 2016, 69, 942-952. doi:10.1016/j.eururo.2015.10.053.

225. Guo, T.; Li, L.; Zhong, Q.; Rupp, N.J.; Charmpi, K.; Wong, C.E.; Wagner, U.; Rueschoff, J.H.; Jochum, W.; Fankhauser, C.D.; Saba, K.; Poyet, C.; Wild, P.J.; Aebersold, R.; Beyer, A. Multi-region proteome analysis quantifies spatial heterogeneity of prostate tissue biomarkers. Life Science Alliance 2018, 1, e201800042. doi:10.26508/lsa.201800042.

226. Latonen, L.; Afyounian, E.; Jylha, A.; Nattinen, J.; Aapola, U.; Annala, M.; Kivinummi, K.K.; Tammela, T.T.L.; Beuerman, R.W.; Uusitalo, H.; Nykter, M.; Visakorpi, T. Integrative proteomics in prostate cancer uncovers robustness against genomic and transcriptomic aberrations during disease progression. Nature Communications 2018, 9, 1176. doi:10.1038/s41467-018-03573-6.

227. Martiny, P.B.; Alcoba, D.D.; Neto, B.S.; Carvalho, P.C.; Brum, I.S. A proteomic glimpse into the oncogenesis of prostate cancer. Journal of Applied Biomedicine 2018, 16, 328-336. doi:10.1016/j.jab.2018.05.003.

228. Kawahara, R.; Recuero, S.; Nogueira, F.C.S.; Domont, G.B.; Leite, K.R.M.; Srougi, M.; Thaysen-Andersen, M.; Palmisano, G. Tissue proteome signatures associated with five grades of prostate cancer and benign prostatic hyperplasia. Proteomics 2019, 19, 1900174. doi:10.1002/pmic.201900174.

229. Mantsiou, A.; Makridakis, M.; Fasoulakis, K.; Katafigiotis, I.; Constantinides, C.A.; Zoidakis, J.; Roubelakis, M.G.; Vlahou, A.; Lygirou, V. Proteomics analysis of formalin fixed paraffin embedded tissues in the investigation of prostate cancer. Journal of Proteome Research 2019, in press. doi:10.1021/acs.jproteome.9b00587.

230. Turiák, L.; Ozohanics, O.; Tóth, G.; Ács, A.; Ágnes Révész.; Vékey, K.; Telekes, A.; Drahos, L. High sensitivity proteomics of prostate cancer tissue microarrays to discriminate between healthy and cancerous tissue. Journal of Proteomics 2019, 197, 82-91. doi:10.1016/j.jprot.2018.11.009.

231. Zhou, B.; Yan, Y.; Wang, Y.; You, S.; Freeman, M.R.; Yang, W. Quantitative proteomic analysis of prostate tissue specimens identifies deregulated protein complexes in primary prostate cancer. Clinical Proteomics 2019, 16, 15. doi:10.1186/s12014-019-9236-2.

232. Kwon, O.K.; Ha, Y.S.; Na, A.Y.; Chun, S.Y.; Kwon, T.G.; Lee, J.N.; Lee, S. Identification of novel prognosis and prediction markers in advanced prostate cancer tissues based on quantitative proteomics. Cancer Genomics - Proteomics 2020, 17, 195-208. doi:10.21873/cgp.20180.

233. Sun, R.; Hunter, C.; Chen, C.; Ge, W.; Morrice, N.; Liang, S.; Zhu, T.; Yuan, C.; Ruan, G.; Zhang, Q.; Cai, X.; Yu, X.; Chen, L.; Dai, S.; Luan, Z.; Aebersold, R.; Zhu, Y.; Guo, T. Accelerated protein biomarker discovery from FFPE tissue samples using single-shot, short gradient microflow SWATH MS. Journal of Proteome Research 2020, in press. doi:10.1021/acs.jproteome.9b00671.

234. Zhu, T.; Zhu, Y.; Xuan, Y.; Gao, H.; Cai, X.; Piersma, S.R.; Pham, T.V.; Schelfhorst, T.; Goeij De Haas, R.R.; Bijnsdorp, I.V.; Sun, R.; Yue, L.; Ruan, G.; Zhang, Q.; Hu, M.; Zhou, Y.; Van Houdt, W.J.; Lelarge, T.; Cloos, J.; Wojtuszkiewicz, A.; Koppers-Lalic, D.; Böttger, F.; Scheepbouwer, C.; Brakenhoff, R.; van Leenders, G.; Ijzermans, J.N.; Martens, J.; Steenbergen, R.; Grieken, N.; Selvarajan, S.; Mantoo, S.; Lee, S.S.; Yi Yeow, S.J.; Alkaff, S.M.F.; Xiang, N.; Sun, Y.; Yi, X.; Dai, S.; Liu, W.; Lu, T.; Wu, Z.; Liang, X.; Wang, M.; Shao, Y.; Zheng, X.; Xu, K.; Yang, Q.; Meng, Y.; Lu, C.; Zhu, J.; Zheng, J.; Wang, B.; Lou, S.; Dai, Y.; Xu, C.; Yu, C.; Ying, H.; Lim, T.K.h.; Wu, J.; Gao, X.; Luan, Z.; Teng, X.; Wu, P.; Huang, S.; Tao, Z.; Iyer, N.G.; Zhou, S.; Shao, W.; Lam, H.; Ma, D.; Ji, J.; Kon, O.L.; Zheng, S.; Aebersold, R.; Jimenez, C.R.; Guo, T. DPHL: A pan-human protein mass spectrometry library for robust biomarker discovery. bioRxiv 2020, preprint. doi:10.1101/2020.02.03.931329.

235. Amend, J.P.; LaRowe, D.E.; McCollom, T.M.; Shock, E.L. The energetics of organic synthesis inside and outside the cell. Philosophical Transactions of the Royal Society, B: Biological Sciences 2013, 368, 20120255. doi:10.1098/rstb.2012.0255.

236. Dick, J.M.; Shock, E.L. Calculation of the relative chemical stabilities of proteins as a function of temperature and redox chemistry in a hot spring. PLOS One 2011, 6, e22782. doi:10.1371/journal.pone.0022782.

237. Dick, J.M. Average oxidation state of carbon in proteins. Journal of the Royal Society Interface 2014, 11, 20131095. doi:10.1098/rsif.2013.1095.

238. Bolker, B.M. Ecological Models and Data in R; Princeton University Press: Princeton, NJ, 2008.

239. Venables, W.N.; Ripley, B.D. Modern Applied Statistics with S, 4th ed.; Springer: New York, 2002. http:/ / www.stats.ox.ac.uk/pub/MASS4, doi:10.1007/978-0-387-21706-2. 
240. Trigos, A.S.; Pearson, R.B.; Papenfuss, A.T.; Goode, D.L. Altered interactions between unicellular and multicellular genes drive hallmarks of transformation in a diverse range of solid tumors. Proceedings of the National Academy of Sciences 2017, 114, 6406-6411. doi:10.1073/pnas.1617743114.

241. Liebeskind, B.J.; McWhite, C.D.; Marcotte, E.M. Towards consensus gene ages. Genome Biology and Evolution 2016, 8, 1812-1823. doi:10.1093/gbe/evw113.

242. R Core Team. R: A Language and Environment for Statistical Computing. R Foundation for Statistical Computing, Vienna, Austria, 2020. https:/ /www.R-project.org.

243. National Cancer Institute. TCGA Study Abbreviations. https://gdc.cancer.gov/resources-tcga-users/tcga-code-tables/tcga-st last accessed on 2020-01-30, 2018.

244. Uhlén, M.; Fagerberg, L.; Hallström, B.M.; Lindskog, C.; Oksvold, P.; Mardinoglu, A.; Sivertsson, Å.; Kampf, C.; Sjöstedt, E.; Asplund, A.; Olsson, I.; Edlund, K.; Lundberg, E.; Navani, S.; Szigyarto, C.A.K.; Odeberg, J.; Djureinovic, D.; Takanen, J.O.; Hober, S.; Alm, T.; Edqvist, P.H.; Berling, H.; Tegel, H.; Mulder, J.; Rockberg, J.; Nilsson, P.; Schwenk, J.M.; Hamsten, M.; von Feilitzen, K.; Forsberg, M.; Persson, L.; Johansson, F.; Zwahlen, M.; von Heijne, G.; Nielsen, J.; Pontén, F. Tissue-based map of the human proteome. Science 2015, 347, 1260419. doi:10.1126/science.1260419.

245. Tang, Z.; Kang, B.; Li, C.; Chen, T.; Zhang, Z. GEPIA2: An enhanced web server for large-scale expression profiling and interactive analysis. Nucleic Acids Research 2019, 47, W556-W560. doi:10.1093/nar/gkz430.

246. Goldman, M.; Craft, B.; Hastie, M.; Repečka, K.; McDade, F.; Kamath, A.; Banerjee, A.; Luo, Y.; Rogers, D.; Brooks, A.N.; Zhu, J.; Haussler, D. The UCSC Xena platform for public and private cancer genomics data visualization and interpretation. bioRxiv 2019, preprint. doi:10.1101/326470.

247. GTEx Consortium. Genetic effects on gene expression across human tissues. Nature 2017, 550, $204-213$. doi:10.1038/nature24277.

248. The Cancer Genome Atlas Research Network.; Weinstein, J.N.; Collisson, E.A.; Mills, G.B.; Shaw, K.R.M.; Ozenberger, B.A.; Ellrott, K.; Sander, I.S.C.; Stuart, J.M. The Cancer Genome Atlas Pan-Cancer analysis project. Nature Genetics 2013, 45, 1113-1120. doi:10.1038/ng.2764.

249. Uhlen, M.; Zhang, C.; Lee, S.; Sjöstedt, E.; Fagerberg, L.; Bidkhori, G.; Benfeitas, R.; Arif, M.; Liu, Z.; Edfors, F.; Sanli, K.; von Feilitzen, K.; Oksvold, P.; Lundberg, E.; Hober, S.; Nilsson, P.; Mattsson, J.; Schwenk, J.M.; Brunnström, H.; Glimelius, B.; Sjöblom, T.; Edqvist, P.H.; Djureinovic, D.; Micke, P.; Lindskog, C.; Mardinoglu, A.; Ponten, F. A pathology atlas of the human cancer transcriptome. Science 2017, 357, eaan2507. doi:10.1126/science.aan2507.

250. Chen, G.; Gharib, T.G.; Huang, C.C.; Taylor, J.M.G.; Misek, D.E.; Kardia, S.L.R.; Giordano, T.J.; Iannettoni, M.D.; Orringer, M.B.; Hanash, S.M.; Beer, D.G. Discordant protein and mRNA expression in lung adenocarcinomas. Molecular \& Cellular Proteomics 2002, 1, 304-313. doi:10.1074/mcp.M200008-MCP200.

251. Greenbaum, D.; Colangelo, C.; Williams, K.; Gerstein, M. Comparing protein abundance and mRNA expression levels on a genomic scale. Genome Biology 2003, 4, 117. doi:10.1186/gb-2003-4-9-117.

252. Zhang, Y.J.; Zhu, C.; Ding, Y.; Yan, Z.W.; Li, G.H.; Lan, Y.; Wen, J.F.; Chen, B. Subcellular stoichiogenomics reveal cell evolution and electrostatic interaction mechanisms in cytoskeleton. BMC Genomics 2018, 19, 469. doi:10.1186/s12864-018-4845-0.

253. Vohra, R.; Park, J.; Wang, Y.N.; Gravelle, K.; Whang, S.; Hwang, J.H.; Lee, D. Evaluation of pancreatic tumor development in KPC mice using multi-parametric MRI. Cancer Imaging 2018, $18,41$. doi:10.1186/s40644-018-0172-6.

254. Genina, E.A.; Bashkatov, A.N.; Tuchina, D.K.; (Timoshina), P.A.D.; Navolokin, N.; Shirokov, A.; Khorovodov, A.; Terskov, A.; Klimova, M.; Mamedova, A.; Blokhina, I.; Agranovich, I.; Zinchenko, E.; Semyachkina-Glushkovskaya, O.V.; Tuchin, V.V. Optical properties of brain tissues at the different stages of glioma development in rats: pilot study. Biomedical Optics Express 2019, 10, 5182-5197. doi:10.1364/BOE.10.005182.

255. Ali, J.H.; Wang, W.B.; Zevallos, M.; Alfano, R.R. Near infrared spectroscopy and imaging to probe differences in water content in normal and cancer human prostate tissues. Technology in Cancer Research $\mathcal{E}$ Treatment 2004, 3, 491-497. doi:10.1177/153303460400300510.

256. Parker, C.; Milosevic, M.; Toi, A.; Sweet, J.; Panzarella, T.; Bristow, R.; Catton, C.; Catton, P.; Crook, J.; Gospodarowicz, M.; McLean, M.; Warde, P.; Hill, R.P. Polarographic electrode study of tumor oxygenation in clinically localized prostate cancer. International Journal of Radiation Oncology*Biology*Physics 2004, 58, 750-757. doi:10.1016/S0360-3016(03)01621-3. 
257. Eidelman, E.; Twum-Ampofo, J.; Ansari, J.; Siddiqui, M.M. The metabolic phenotype of prostate cancer. Frontiers in Oncology 2017, 7, 131. doi:10.3389/fonc.2017.00131.

258. Hochachka, P.; Rupert, J.; Goldenberg, L.; Gleave, M.; Kozlowski, P. Going malignant: The hypoxia-cancer connection in the prostate. Bioessays 2002, 24, 749-757. doi:10.1002/bies.10131.

259. Zhou, J.X.; Cisneros, L.; Knijnenburg, T.; Trachana, K.; Davies, P.; Huang, S. Phylostratigraphic analysis of tumor and developmental transcriptomes reveals relationship between oncogenesis, phylogenesis and ontogenesis. Convergent Science Physical Oncology 2018, 4, 025002. doi:10.1088/2057-1739/aab1b0.

260. Brocchieri, L.; Karlin, S. Protein length in eukaryotic and prokaryotic proteomes. Nucleic Acids Research 2005, 33, 3390-3400. doi:10.1093/nar/gki615.

261. Moyers, B.A.; Zhang, J. Further simulations and analyses demonstrate open problems of phylostratigraphy. Genome Biology and Evolution 2017, 9, 1519-1527. doi:10.1093/gbe/evx109.

262. Yin, Y.; Li, B.; Mou, K.; Khan, M.T.; Kaushik, A.C.; Wei, D.; Zhang, Y.J. Stoichioproteomics reveal oxygen usage bias, key proteins and pathways in glioma. BMC Medical Genomics 2019, 12, 125. doi:10.1186/s12920-019-0571-y.

263. Zuo, X.; Li, B.; Zhu, C.; Yan, Z.W.; Li, M.; Wang, X.; Zhang, Y.J. Stoichiogenomics reveal oxygen usage bias, key proteins and pathways associated with stomach cancer. Scientific Reports 2019, 9, 11344. doi:10.1038/s41598-019-47533-6.

264. Harris, B.H.L.; Barberis, A.; West, C.M.L.; Buffa, F.M. Gene expression signatures as biomarkers of tumour hypoxia. Clinical Oncology 2015, 27, 547-560. doi:10.1016/j.clon.2015.07.004.

265. Bhandari, V.; Hoey, C.; Liu, L.Y.; Lalonde, E.; Ray, J.; Livingstone, J.; Lesurf, R.; Shiah, Y.J.; Vujcic, T.; Huang, X.; Espiritu, S.M.G.; Heisler, L.E.; Yousif, F.; Huang, V.; Yamaguchi, T.N.; Yao, C.Q.; Sabelnykova, V.Y.; Fraser, M.; Chua, M.L.K.; van der Kwast, T.; Liu, S.K.; Boutros, P.C.; Bristow, R.G. Molecular landmarks of tumor hypoxia across cancer types. Nature Genetics 2019, 51, 308-318. doi:10.1038/s41588-018-0318-2.

266. Baudouin-Cornu, P.; Thomas, D. Oxygen at life's boundaries. Nature 2007, 445, $35-36$. doi:10.1038/nature05521.

267. Dick, J.M. Calculation of the relative metastabilities of proteins in subcellular compartments of Saccharomyces cerevisiae. BMC Systems Biology 2009, 3, 75. doi:10.1186/1752-0509-3-75.

268. Beall, P.T. States of water in biological systems. Cryobiology 1983, 20, 324-334. doi:10.1016/0011-2240(83)90021-4.

269. Sun, Q.; He, Y.; Liu, K.; Fan, S.; Parrott, E.P.J.; Pickwell-MacPherson, E. Recent advances in terahertz technology for biomedical applications. Quantitative Imaging in Medicine and Surgery 2017, 7, 345-355. doi:10.21037/qims.2017.06.02.

270. Tsai, H.J.; Nelliat, A.R.; Choudhury, M.I.; Kucharavy, A.; Bradford, W.D.; Cook, M.E.; Kim, J.; Mair, D.B.; Sun, S.X.; Schatz, M.C.; Li, R. Hypo-osmotic-like stress underlies general cellular defects of aneuploidy. Nature 2019, 570, 117-121. doi:10.1038/s41586-019-1187-2.

271. Gasch, A.P.; Spellman, P.T.; Kao, C.M.; Carmel-Harel, O.; Eisen, M.B.; Storz, G.; Botstein, D.; Brown, P.O. Genomic expression programs in the response of yeast cells to environmental changes. Molecular Biology of the Cell 2000, 11, 4241-4257. doi:10.1091/mbc.11.12.4241.

272. Yang, L.; Yurkovich, J.T.; Lloyd, C.J.; Ebrahim, A.; Saunders, M.A.; Palsson, B.O. Principles of proteome allocation are revealed using proteomic data and genome-scale models. Scientific Reports 2016, 6, 36734. doi:10.1038/srep36734.

273. Karlin, S.; Brendel, V. Chance and statistical significance in protein and DNA sequence analysis. Science 1992, 257, 39-49. doi:10.1126/science.1621093.

274. Gunde-Cimerman, N.; Plemenitaš, A.; Oren, A. Strategies of adaptation of microorganisms of the three domains of life to high salt concentrations. FEMS Microbiology Reviews 2018, 42, 353-375. doi:10.1093/femsre/fuy009.

275. Record, Jr., M.T.; Courtenay, E.S.; Cayley, D.S.; Guttman, H.J. Responses of E. coli to osmotic stress: Large changes in amounts of cytoplasmic solutes and water. Trends in Biochemical Sciences 1998, 23, 143-148. doi:10.1016/S0968-0004(98)01196-7.

276. Staunton, J.R.; So, W.Y.; Paul, C.D.; Tanner, K. High-frequency microrheology in 3D reveals mismatch between cytoskeletal and extracellular matrix mechanics. Proceedings of the National Academy of Sciences 2019, 116, 14448-14455. doi:10.1073/pnas.1814271116. 
277. Acland, M.; Mittal, P.; Lokman, N.A.; Klingler-Hoffmann, M.; Oehler, M.K.; Hoffmann, P. Mass spectrometry analyses of multicellular tumor spheroids. Proteomics: Clinical Applications 2018, 12, 1700124. doi:10.1002/prca.201700124.

278. Monnier, S.; Delarue, M.; Brunel, B.; Dolega, M.E.; Delon, A.; Cappello, G. Effect of an osmotic stress on multicellular aggregates. Methods 2016, 94, 114-119. doi:10.1016/j.ymeth.2015.07.009.

279. Jung, H.J.; Park, J.Y.; Jeon, H.S.; Kwon, T.H. Aquaporin-5: A marker protein for proliferation and migration of human breast cancer cells. PLOS One 2011, 6, e28492. doi:10.1371/journal.pone.0028492.

280. Havard, M.; Dautry, F.; Tchénio, T. A dormant state modulated by osmotic pressure controls clonogenicity of prostate cancer cells. Journal of Biological Chemistry 2011, 286, 44177-44186. doi:10.1074/jbc.M111.262709.

281. Schliess, F.; Reinehr, R.; Häussinger, D. Osmosensing and signaling in the regulation of mammalian cell function. FEBS Journal 2007, 274, 5799-5803. doi:10.1111/j.1742-4658.2007.06100.x.

282. Marakhova, I.; Yurinskaya, V.; Aksenov, N.; Zenin, V.; Shatrova, A.; Vereninov, A. Intracellular $\mathrm{K}^{+}$and water content in human blood lymphocytes during transition from quiescence to proliferation. Scientific Reports 2019, 9, 16253. doi:10.1038/s41598-019-52571-1.

283. Hanahan, D.; Weinberg, R.A. Hallmarks of cancer: The next generation. Cell 2011, 144, 646-674. doi:10.1016/j.cell.2011.02.013.

284. Gromov, P.; Moreira, J.M.; Gromova, I. Proteomic analysis of tissue samples in translational breast cancer research. Expert Review of Proteomics 2014, 11, 285-302. doi:10.1586/14789450.2014.899469.

285. Fujii, K.; Nakamura, H.; Nishimura, T. Recent mass spectrometry-based proteomics for biomarker discovery in lung cancer, COPD, and asthma. Expert Review of Proteomics 2017, 14, 373-386. doi:10.1080/14789450.2017.1304215.

286. Calabrese, F.; Lunardi, F.; Pezzuto, F.; Fortarezza, F.; Vuljan, S.E.; Marquette, C.; Hofman, P. Are there new biomarkers in tissue and liquid biopsies for the early detection of non-small cell lung cancer? Journal of Clinical Medicine 2019, 8, 414. doi:10.3390/jcm8030414.

287. Bolstad, B.; Irizarry, R.; Åstrand, M.; Speed, T. A comparison of normalization methods for high density oligonucleotide array data based on variance and bias. Bioinformatics 2003, 19, 185-193. doi:10.1093/bioinformatics/19.2.185.

288. Huang, H.; McGarvey, P.B.; Suzek, B.E.; Mazumder, R.; Zhang, J.; Chen, Y.; Wu, C.H. A comprehensive protein-centric ID mapping service for molecular data integration. Bioinformatics 2011, 27, 1190-1191. doi:10.1093/bioinformatics/btr101.

289. Dick, J.M. CHNOSZ: Thermodynamic calculations and diagrams for geochemistry. Frontiers in Earth Science 2019, 7, 180. doi:10.3389/feart.2019.00180.

290. The Human Protein Atlas. Dictionary: Pathology Overview. https: / / www.proteinatlas.org/learn/dictionary/pathology last accessed on 2020-01-31, 2019.

291. GEPIA2. Dataset Sources. http://gepia2.cancer-pku.cn/\#dataset last accessed on 2020-01-31, 2019.

292. Liebeskind, B.; McWhite, C.D.; Hines, K. Gene-Ages v1.0. https://doi.org/10.5281/zenodo.51708, 2016.

293. Dick, J.M. canprot 1.0.0. https:// doi.org/10.5281/zenodo.3820154, 2020.

294. Dick, J.M. JMDplots 1.2.2. https://doi.org/10.5281/zenodo.3824121, 2020. 